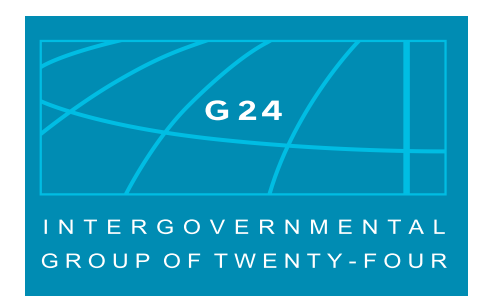

G-24 Discussion Paper Series

\title{
Global Liquidity and Financial Flows to Developing Countries: New Trends in Emerging Markets and their Implications
}

C.P. Chandrasekhar

No. 52, November 2008

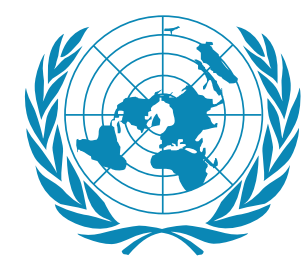

UNITED NATIONS 



\section{G-24 Discussion Paper Series}

Research papers for the Intergovernmental Group of Twenty-Four on International Monetary Affairs and Development

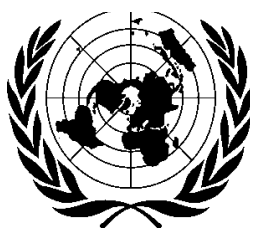

UNITED NATIONS

New York and Geneva, November 2008 


\section{Note}

Symbols of United Nations documents are composed of capital letters combined with figures. Mention of such a symbol indicates a reference to a United Nations document.

The views expressed in this Series are those of the authors and do not necessarily reflect the views of the UNCTAD secretariat. The designations employed and the presentation of the material do not imply the expression of any opinion whatsoever on the part of the Secretariat of the United Nations concerning the legal status of any country, territory, city or area, or of its authorities, or concerning the delimitation of its frontiers or boundaries.

Material in this publication may be freely quoted; acknowledgement, however, is requested (including reference to the document number). It would be appreciated if a copy of the publication containing the quotation were sent to the Publications Assistant, Division on Globalization and Development Strategies, UNCTAD, Palais des Nations, CH-1211 Geneva 10.

UNITED NATIONS PUBLICATION

UNCTAD/GDS/MDP/G24/2008/3

Copyright (C) United Nations, 2008

All rights reserved 


\section{PREFACE}

The G-24 Discussion Paper Series is a collection of research papers prepared under the UNCTAD Project of Technical Support to the Intergovernmental Group of Twenty-Four on International Monetary Affairs and Development (G-24). The G-24 was established in 1971 with a view to increasing the analytical capacity and the negotiating strength of the developing countries in discussions and negotiations in the international financial institutions. The G-24 is the only formal developing-country grouping within the IMF and the World Bank. Its meetings are open to all developing countries.

The G-24 Project, which is administered by UNCTAD's Division on Globalization and Development Strategies, aims at enhancing the understanding of policy makers in developing countries of the complex issues in the international monetary and financial system, and at raising awareness outside developing countries of the need to introduce a development dimension into the discussion of international financial and institutional reform.

The research papers are discussed among experts and policy makers at the meetings of the G-24 Technical Group, and provide inputs to the meetings of the G-24 Ministers and Deputies in their preparations for negotiations and discussions in the framework of the IMF's International Monetary and Financial Committee (formerly Interim Committee) and the Joint IMF/IBRD Development Committee, as well as in other forums.

The Project of Technical Support to the G-24 receives generous financial support from the International Development Research Centre of Canada and contributions from the countries participating in the meetings of the G-24. 



\section{GLOBAL LIQUIDITY AND FINANCIAL FLOWS TO DEVELOPING COUNTRIES: \\ New Trends in Emerging Markets and their Implications}

\section{C.P. Chandrasekhar}

Professor at the Centre for Economic Studies and Planning, School of Social Sciences, Jawaharlal Nehru University

\section{G-24 Discussion Paper No. 52}

November 2008 



\begin{abstract}
After a slump in cross-border financial flows of capital in the years following the East Asian financial crisis, capital flows to developing countries have seen a robust revival in recent years. This paper attempts to examine: (i) the factors responsible for this revival and surge in capital flows into developing countries; (ii) the qualitative changes in financial integration that are accompanying this surge; and (iii) the impact that this surge is having on financial volatility and vulnerability, macroeconomic management and growth, in countries that have been "successful" in attracting such flows.

It argues that in the wake of financial liberalization that facilitates cross-border flows of capital, supply-side factors rather than the financing requirements of developing countries, explain the surge. Financial liberalization and the globalization of finance, have also resulted in changes in the financial structure - the markets, institutions and instruments that define the global financial architecture. Increasingly a small number of centralized financial institutions intermediate global capital flows and the investment decisions of a few individuals in these institutions determine the nature of the "exposure" of the global financial system. This has implications for the accumulation of risk and vulnerability to financial crisis in markets where agents tend to herd.

Associated with this increasing risk, are changes in the business practices and motivations of financial firms that reduce the role of finance in ensuring broad-based economic growth. Together with the constraints on fiscal, exchange rate and monetary policy set by large capital flows, this can limit the prospects of long-run, noninflationary growth as well.
\end{abstract}



Abbreviations

$\begin{array}{ll}\text { BIS } & \text { Bank of International Settlements } \\ \text { CGFS } & \text { Committee on the Global Financial System } \\ \text { CIC } & \text { China Investment Corporation } \\ \text { EMEs } & \text { emerging market economies } \\ \text { FDI } & \text { foreign direct investment } \\ \text { FII } & \text { foreign institutional investor } \\ \text { FSFDI } & \text { financial sector foreign direct investment } \\ \text { HFR } & \text { hedge fund research } \\ \text { ICBC } & \text { Industrial and Commercial Bank of China } \\ \text { IKB } & \text { Deutsche Industriebank AG } \\ \text { IMF } & \text { International Monetary Fund } \\ \text { IPOs } & \text { initial public offers } \\ \text { KfW } & \text { Kreditanstalt für Wiederaufbau } \\ \text { LTCM } & \text { Long Term Capital Management } \\ \text { M\&A } & \text { merger and acquisition } \\ \text { OECD } & \text { Organisation for Economic Co-operation and Development } \\ \text { OTC } & \text { over-the-counter } \\ \text { RBI } & \text { Reserve Bank of India } \\ \text { WB } & \text { The World Bank }\end{array}$





\section{Table of contents}

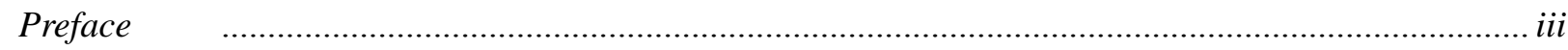

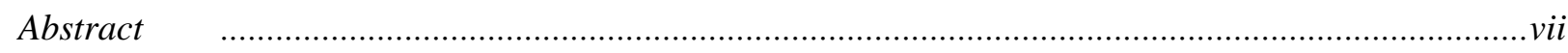

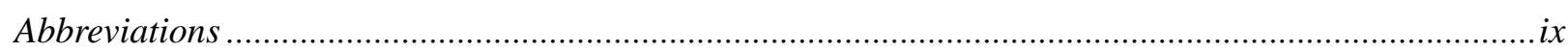

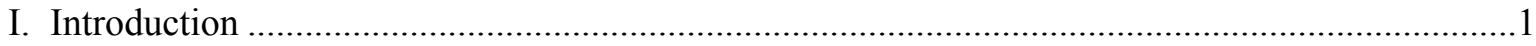

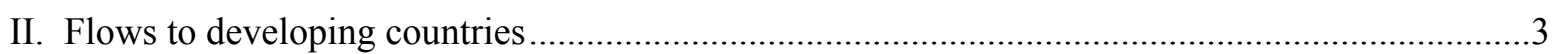

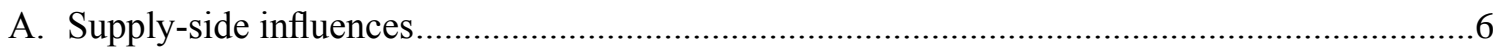

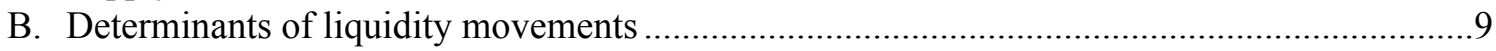

C. Consequences of supply-side capital flow pressures............................................................10

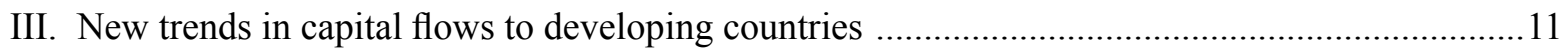

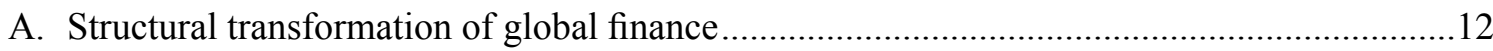

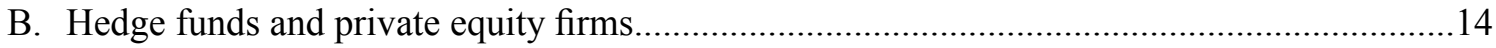

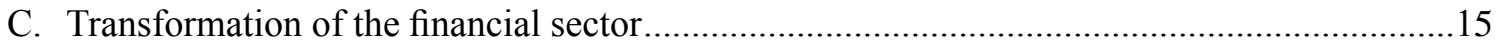

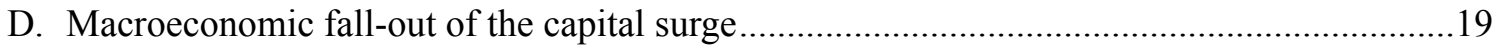

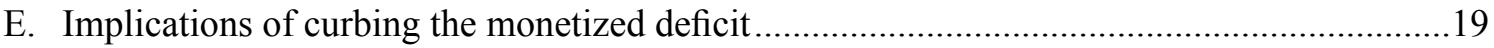

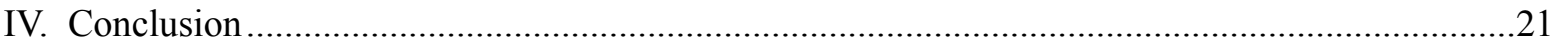

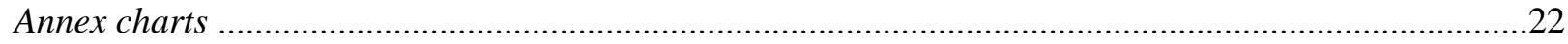

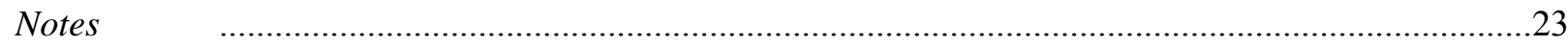

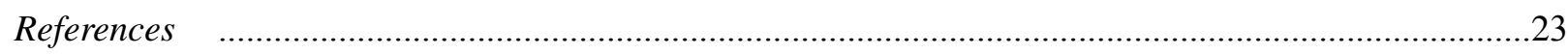

\section{List of tables}

1 Developing countries and other emerging markets: external financing, 1997-2006 ...................2

2 Percentage increase in exposure to different locations by nationality of banks, 2003-2007 .........8

3 Changes in outstanding positions for key international financial assets ....................................8

4 Ownership structure in the banking systems of emerging market economies .............................13

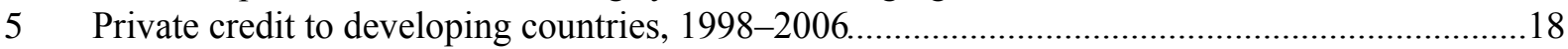

\section{List of charts}

1 Mobilization of capital through equity issues, 1995-2007.......................................................

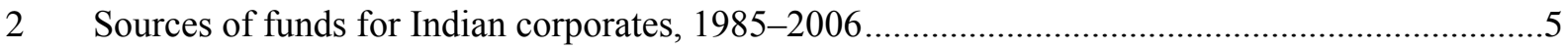

3 Exchange rate adjusted changes in external positions of banks in 23 countries, 1994-2006 .........7

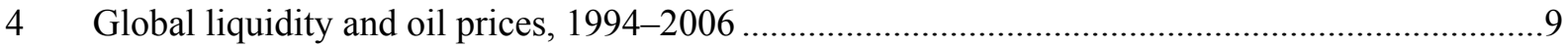

5 Global liquidity and ratio of M3 to GDP in the United States, 1994-2005 ...............................10

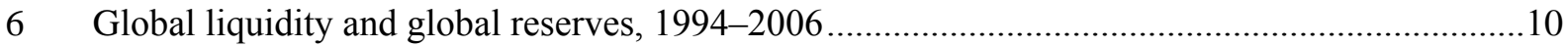





\title{
GLOBAL LIQUIDITY AND FINANCIAL FLOWS TO DEVELOPING COUNTRIES: New Trends in Emerging Markets and their Implications
}

\author{
C.P. Chandrasekhar*
}

\section{Introduction}

After a slump in cross-border flows of capital in the years following the East Asian financial crisis, international financial flows have seen a robust revival in recent years. The magnitude of crossborder transactions has grown exponentially during the current decade. Further, qualitative changes that accompanied this quantitative expansion have transformed the nature of the financial integration of developing countries with their developed country counterparts.

This paper examines: (i) the factors responsible for this surge in capital flows into developing countries; (ii) the qualitative changes in financial integration accompanying this surge; and (iii) the impact that this surge is having on financial volatility and vulnerability, macroeconomic management and growth, in countries that have been "successful" in attracting such flows. Besides data from developing countries as a group, evidence from one country that epitomizes the effects of the recent surge in capital flows, viz., India, is used to illustrate the effects that recent trends have on macroeconomic policy and growth.
Measuring the absolute size of globally dispersed finance capital is indeed a difficult proposition. Given the diversity of agents, instruments and markets and the lack of transparency in certain over-the-counter markets, it is extremely difficult to gauge the size of the corpus that functions as international finance. Nevertheless, available figures do point to galloping growth in the global operations of financial firms.

One obvious form this has taken since the international lending boom of the late 1970s is the expansion of operations of international banks in less developed countries, especially the so-called "emerging markets". The net result has been an increase in the international assets of the big banks of the developed world. This trend has only gained strength in recent years. At the time of the East Asian crisis (mid-1997), the international asset position of banks resident in 23 countries reporting to the Bank of International Settlements (BIS) stood at $\$ 9.95$ trillion, involving $\$ 8.6$ trillion in external assets after adjusting for local assets in international currencies (BIS, 1997). By June 2007, when 40 countries were reporting, this had risen to $\$ 33.71$ trillion, with external assets totalling \$29.98 trillion (BIS, 2007a). This expansion in international assets was not only

\footnotetext{
* This work was carried out under the UNCTAD Project of Technical Assistance to the Intergovernmental Group of Twenty-Four on International Monetary Affairs and Development with the aid of a grant from the International Development Research Centre of Canada.
} 
Table 1

\section{DEVELOPING COUNTRIES AND OTHER EMERGING MARKETS: EXTERNAL FINANCING, 1997-2006}

(Billions of dollars)

\begin{tabular}{lrrrrrrrrrr}
\hline & 1997 & 1988 & 1999 & 2000 & 2001 & 2002 & 2003 & 2004 & 2005 & 2006 \\
\hline Balance on current account & -85.6 & -113.4 & -21.2 & 85.8 & 39.4 & 77.3 & 147.6 & 212.6 & 428.0 & 544.2 \\
Net external financing & 360.1 & 265.9 & 230.7 & 240.3 & 182.2 & 173.5 & 311.0 & 479.6 & 607.0 & 785.5 \\
Non-debt-creating flows & 197.7 & 185.7 & 184.8 & 202.1 & 171.4 & 151.3 & 190.0 & 283.6 & 371.1 & 491.0 \\
Capital transfers & 19.8 & 6.4 & 9.5 & 21.0 & 1.9 & -2.5 & 7.7 & 8.3 & 5.6 & 44.2 \\
Foreign direct investment (FDI) & & & & & & & & & & \\
and equity & & & & & & & & & & \\
$\quad \begin{array}{l}\text { Security liabilities } \\
\text { Net external borrowing }\end{array}$ & 177.9 & 179.3 & 175.3 & 181.1 & 169.5 & 153.8 & 182.3 & 275.2 & 365.5 & 446.7 \\
$\quad 162.4$ & 50.2 & 45.9 & 38.2 & 10.9 & 22.2 & 121.0 & 196.0 & 235.9 & 294.5 \\
$\begin{array}{l}\text { Borrowing from official creditors } \\
\text { of which: }\end{array}$ & 13.0 & 42.7 & 34.5 & -8.1 & 24.1 & 10.6 & 0.7 & -6.4 & -50.9 & -64.5 \\
$\quad \begin{array}{l}\text { Credit and IMF loans } \\
\text { Borrowing from banks }\end{array}$ & 3.3 & 14.0 & -2.4 & -10.9 & 19.0 & 13.4 & 1.7 & -14.9 & -39.9 & -30.1 \\
$\quad \begin{array}{l}\text { Borrowing from other } \\
\quad \text { private creditors }\end{array}$ & 9.6 & 9.4 & -13.0 & -10.9 & -12.5 & -18.0 & 13.8 & 30.8 & 40.1 & 57.8 \\
\hline
\end{tabular}

Source: International Monetary Fund, World Economic Outlook, Biannual, Statistical Appendices, various issues.

Note: External financing is defined as the sum of - with opposite sign - the goods and services balance, net income and current transfers, direct investment abroad, the change in reserve assets, the net acquisition of other assets (such as recorded private portfolio assets, export credit, and the collateral for debt-reduction operations), and the net errors and omissions. Thus, net external financing, according to the definition adopted by the International Monetary Fund (IMF), measures the total amount required to finance the current account, direct investment outflows, net reserve transactions (often at the discretion of the monetary authorities), the net acquisition of non-reserve external assets, and the net transactions underlying the errors and omissions (not infrequently reflecting capital flight).

the result of the increase in the number of reporting countries. ${ }^{1}$ The trend was visible in countries that reported on both dates as well. For example, the international assets of the United Kingdom-based banks had increased from $\$ 1.5$ trillion to $\$ 6.1$ trillion, and that of the United States banks from $\$ 0.74$ trillion to $\$ 2.8$ trillion.

But this was not all. Increasingly non-bank financial firms - pension funds, insurance companies and mutual funds - have emerged as important intermediaries between savers and investors. According to a Bank of International Settlements study (Committee on the Global Financial System, 2007: 5), the total financial assets of institutional investors stood at $\$ 46$ trillion in 2005 . Of this, insurance firms accounted for close to $\$ 17$ trillion, pension funds for
$\$ 12.8$ trillion and mutual funds for $\$ 16.2$ trillion. The United States dominated, accounting for as much as \$21.8 trillion of institutional investors' assets, while the United Kingdom was far behind at just \$4 trillion. Here too, growth has been rapid with total assets more than doubling between 1995 and 2005 from $\$ 10.5$ trillion in the United States and \$1.8 trillion in the United Kingdom. The assets of autonomous pension funds in the United States, for example, rose from $\$ 786$ billion in 1980 to $\$ 1.8$ trillion in $1985, \$ 2.7$ trillion in 1990, $\$ 4.8$ trillion in 1995, $\$ 7.4$ trillion in 2000 and $\$ 8$ trillion in 2004 (OECD, 2001; 2003).

Besides these institutions there are other less regulated and opaque institutions, particularly highly leveraged institutions like hedge funds and private equity firms, which directly manage financial assets for 
high net worth individuals, besides the institutional investors themselves. Assets managed by around 9000 surviving hedge funds are now placed at around $\$ 1.6$ trillion (Financial Stability Forum, 2007). And, according to one study, private equity assets under management were nearing $\$ 400$ billion in the United States and just under $\$ 200$ billion in Europe. Private equity expansion is also reportedly strong, with aggregate deal value growing at 51 per cent annually from 2001 to 2005 in North America. ${ }^{2}$

Transactions other than in debt and equity by these entities have also risen rapidly. In 1992, the daily volume of foreign exchange transactions in international financial markets stood at $\$ 820$ billion, compared to the annual world merchandise exports of $\$ 3.8$ trillion or a daily value of world merchandise trade of $\$ 10.3$ billion. According to a recent BIS report (BIS, 2007b: 5) the average daily turnover (adjusted for double-counting) in foreign exchange markets rose from $\$ 800$ billion in 1992 to $\$ 1.5$ trillion in 1998 , before declining to $\$ 1.2$ trillion in 2001 . It then rose to $\$ 1.9$ trillion in 2004 and then sharply to $\$ 3.2$ trillion in 2007. With the average GDP generated globally in a day standing at close to $\$ 100$ trillion in 2003 , this appears to be a small 3 per cent relative to real economic activity across the globe in that year. But the sum involved is huge relative to the daily value of world trade. In 2006, the annual value of world merchandise exports touched $\$ 11.8$ trillion, while that of commercial services trade rose to $\$ 2.7$ trillion. Thus the daily volume of transactions in foreign exchange markets exceeded the annual value of trade in commercial services and was close to a third of the annual merchandise trade.

More significant is the trade in derivatives. The notional value of outstanding over-the-counter derivatives has risen from $\$ 169.7$ trillion in June 2003 to $\$ 516.4$ trillion in June 2007. The BIS estimates (BIS, 2007b: 10) that the average daily turnover of exchange-traded derivatives rose from $\$ 1.4$ trillion in 1998 to $\$ 2.2$ trillion in 2001, $\$ 4.5$ trillion in 2004, and $\$ 6.2$ trillion in April 2007. In the over-the-counter (OTC) derivatives market, average daily turnover amounted to another \$2 trillion in 2007 at current exchange rates (as compared with $\$ 1.2$ trillion, $\$ 575$ billion and $\$ 375$ billion respectively in 2004, 2001, and 1998). Thus total derivatives trading stood at $\$ 8.2$ trillion a day, which together with the $\$ 3.2$ trillion daily turnover in foreign exchange markets adds up to $\$ 11.4$ trillion. This almost equals the annual value of global merchandise exports in 2006.

\section{Flows to developing countries}

This massive expansion of finance capital has been accompanied by a substantial increase in capital flows to developing countries. Net external financing flows which had fallen from \$360.1 billion in 1997 to $\$ 173.5$ billion in 2002 , have since risen sharply to $\$ 785.5$ billion in 2006 . While foreign direct and portfolio investment increased from $\$ 153.8$ billion in 2002 to $\$ 446.7$ billion in 2006 , net external borrowing rose from \$10.9 billion in 2001 to 294.5 billion in 2006. Thus, underlying the surge was an expansion in both investment and debt flows to developing countries.

Two features considered reassuring are, first, the large and dominant share of non-debt creating investment flows and, second, the dominance of foreign direct investment over foreign portfolio investment in equity flows. Since direct investment is assumed to consist of investment aimed at establishing a productive presence in the host country, it is perceived as "long term" in nature. This is contrasted with portfolio flows often considered "hot money" flows looking for quick returns in the stock market.

In actual fact, however, the distinction between direct and portfolio investment is more notional than real. With countries adopting the IMF definition, any investment by a single foreign investor in more than 10 per cent of the equity of a host country firm is defined as direct investment. However, with regulations regarding foreign portfolio investment having been relaxed in most developing countries and the volume of capital looking for portfolio investment opportunities increasing substantially, the number of acquisitions motivated by "portfolio investment" considerations involving purchases of a more than 10 per cent equity stake by a single investor has increased greatly. These acquisitions, whether made through the stock market or through negotiated purchases of stakes in listed or unlisted firms by private equity investors, are not necessarily driven by long run investment considerations, but by the desire to garner large returns from capital gains. Thus, just as in the case of portfolio investment and debt, there is an element of volatility built into such foreign direct investment inflows as well. Do developing countries need this capital? While the search for higher interest rates and larger capital gains underlies the surge in capital flows, these flows are not required by most developing countries for balance of payments financing purposes. Between 2002 and 2006, when external 


\section{Chart 1}

MOBILIZATION OF CAPITAL THROUGH EQUITY ISSUES, 1995-2007

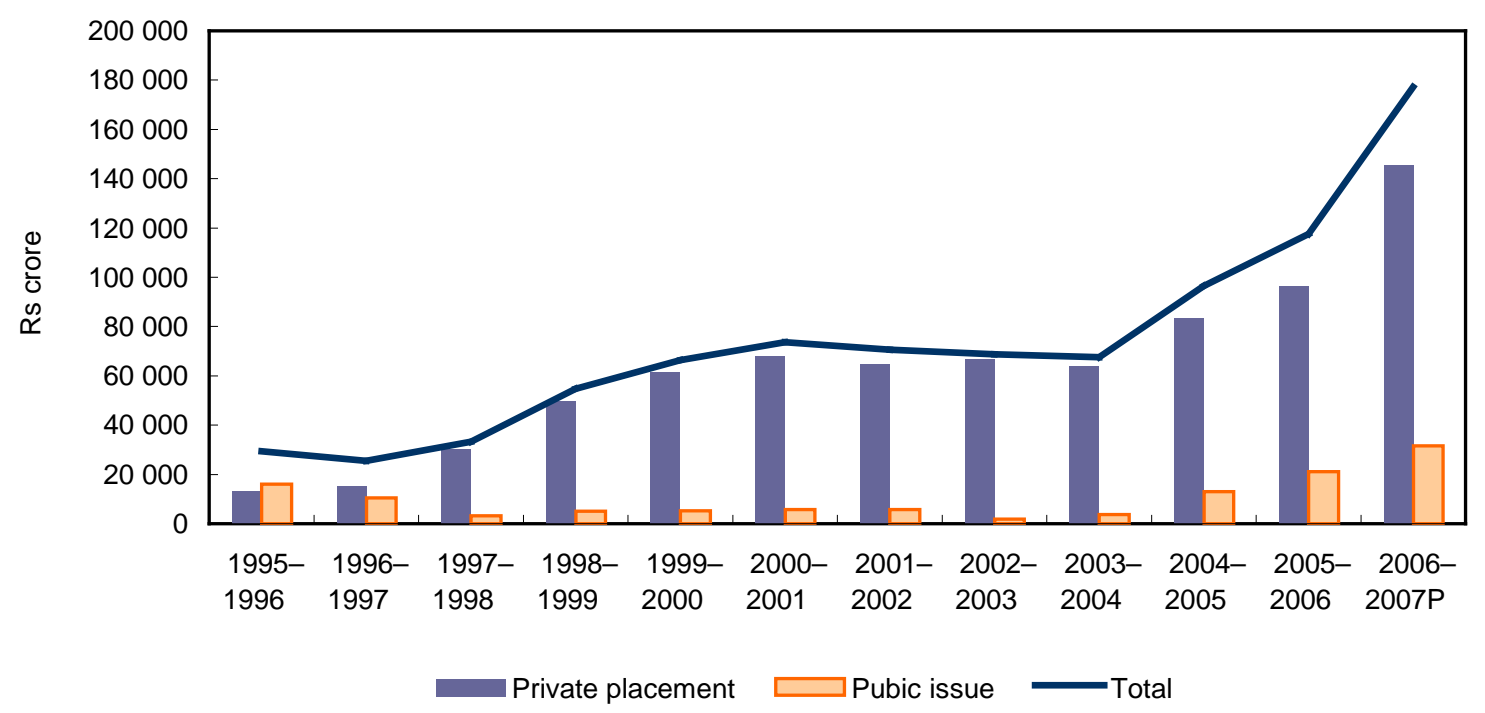

Source: Reserve Bank of India, Handbook of Statistics on Indian Economy, 2007 . Tables 77 and 82. Available at: http://rbidocs. rbi.org.in/rdocs/Publications/DOCs/80257.xls and http://rbidocs.rbi.org.in/rdocs/Publications/DOCs/80262.xls. Accessed 2 January 2008.

Note: 1 crore rupee $=10$ million rupees. $\mathrm{P}=$ provisonal.

financing to developing countries and emerging markets (as defined by the IMF) rose from $\$ 174$ billion to $\$ 786$ billion, developing countries and emerging markets as a group (as defined by the IMF) recorded consistent current account surpluses, with the surplus rising from $\$ 77.3$ billion to $\$ 544$ billion. What is more, a few developing countries recording either small deficits or large surpluses on their current account received the major share of external financing.

The argument that still sounds credible is that such flows help finance the investment boom that underlies the acceleration of growth in developing countries. If the evidence from a successful emerging market like India is any indication, there does seem to be some basis for this argument. Between 2003-2004 and 2006-2007, which was a period when foreign institutional investor (FII) inflows rose significantly and stock markets were buoyant most of the time, equity capital mobilized by the Indian corporate sector rose from Rs 676.22 billion to Rs $1,771.7$ billion (chart 1).

Not all of this was raised through equity issued in the stock market. In fact a predominant and rapidly growing share, amounting to a huge Rs $1,455.71$ billion in 2006-2007 was raised in the private placement market, involving negotiated sales of chunks of new equity in firms not listed in the stock market to financial investors of various kinds such as merchant banks, hedge funds and private equity firms. While not directly part of the stock market boom, such sales were encouraged by the high valuations generated by that boom and were, as in the case of stock markets, made substantially to foreign financial investors.

One obvious consequence of FII investments in stock markets and unlisted firms is that the possibility of take-over by foreign entities of Indian firms has increased substantially. This possibility of transfer of ownership from Indian to foreign individuals or entities has increased with the private placement boom, which is not restrained by the extent of free-floating shares available for trading in stock markets. Private equity firms can seek out appropriate investment targets and persuade domestic firms to part with a significant share of equity using valuations that would be substantial by domestic wealth standards but not so by international standards. Since private equity expects to make its returns in the medium term, it 


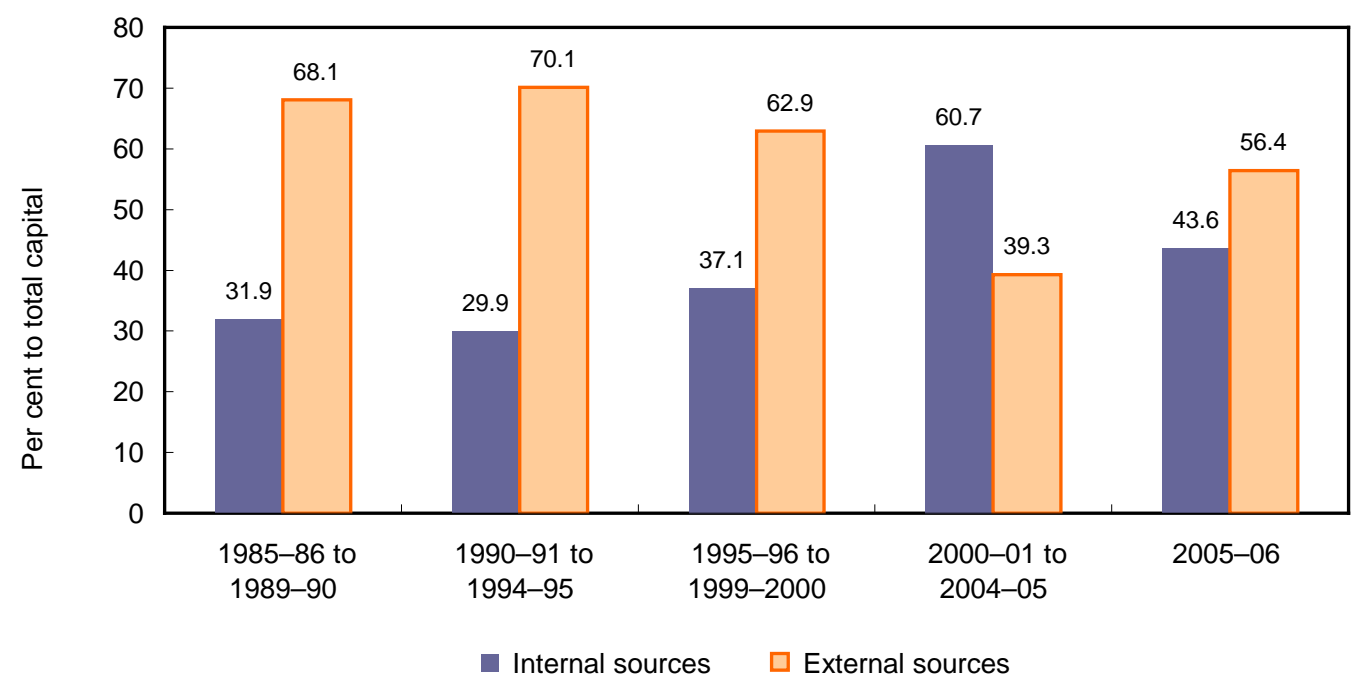

Source: Reserve Bank of India, Report on Currency and Finance, 2006-07. Chapter 7, table 7.5: 268.

can then wait till policies on foreign ownership are adequately relaxed and an international firm is interested in an acquisition in the area concerned. The rapid expansion of private equity in India suggests that this is the route the private equity business is seeking as the potential for such activity in the developed countries is reaching saturation levels.

However, these trends notwithstanding, foreign equity does not account for a significant share of total corporate finance in the country. In fact, internal sources, such as retained profits and depreciation reserves, have accounted for a much higher share of corporate finance during the equity boom of the first half of this decade. According to RBI figures (chart 2), internal sources of finance, which accounted for about 30 per cent of total corporate financing during the second half of the 1980s and the first half of the 1990s, rose to 37 per cent during the second half of the 1990s and to a record 61 per cent during 2000-2001 to 2004-2005. Though that figure fell during 2005-2006, the last year for which RBI studies of company finances are currently available, it still stood at a relatively high 56 per cent.

Among the factors explaining the new dominance of internal sources of finance, three are of importance. First, increased corporate surpluses, resulting from enhanced sales and a combination of rising productivity and stagnant real wages. Second, a lower interest burden, resulting from the sharp decline in nominal interest rates, compared to the $1980 \mathrm{~s}$ and early 1990s. And third, reduced tax deductions, because of tax concessions and loopholes. These factors have combined to leave more cash in the hands of corporations for expansion and modernization.

Along with the increased role for internally generated funds in corporate financing in recent years, the share of equity in all forms of external finance has also been declining. An examination of the composition of external financing (measured relative to total financing) shows that the share of equity capital in total financing, that had risen from 7 to 19 per cent between the second half of the 1980s and the first half of the 1990s, subsequently declined by 13 and 10 per cent respectively during the second half of the 1990s and the first half of this decade. There, however, appears to be a revival to 17 per cent of equity financing in 2005-2006, possibly as a result of the private placement boom of recent times.

What is noteworthy is that, with the decline of development banking and therefore of the provision 
of finance by such financial institutions (which have been converted into commercial banks), the role of commercial banks in financing the corporate sector has risen sharply to touch 24 per cent of the total in 2003-2004. In sum, internal resources and bank finance dominate corporate financing, and not equity, which receives all the attention because of the surge in foreign institutional investment and the media's obsession with stock market buoyancy.

Thus, the surge in foreign financial investment is important, more because of the impact that it has on the pattern of corporate sector ownership rather than the contribution it makes to corporate finance. This challenges the defence of the open door policy to foreign financial investment on the grounds that it helps mobilize resources for investment. It also increases the threat of widespread foreign take over associated with this policy.

\section{A. Supply-side influences}

If the needs or requirements of developing countries are not responsible for the surge in capital inflows, what are the determining influences? There is reason to believe that the capital flows to developing countries (before netting out the investment of their large reserves in external markets) were driven more by supply-side push factors, rather than developing country demand. It is undoubtedly true that this capital could not have crossed borders without relaxed regulations regarding the inflow of foreign equity and debt in the developing countries. But liberalization has not ensured large inflows either in all countries or at all times. It appears that an expansion of liquidity in the international financial system has driven funds into emerging markets, as it did before the debt crisis in the early 1980s and the East Asian crisis in 1997.

Markets are liquid when those who hold assets can sell them at prices that do not involve significant losses, so as to access the finance they need to meet other commitments. Given its definition, measuring liquidity is near impossible. But, as is well recognized, a market is more liquid when there are more investors active in that market. So the volume of transactions occurring in markets is an indicator of the extent of liquidity in the system. Despite the diversified and complex nature of financial markets today, the banking sector sits at the centre of the financial system, mobilizing and allocating much of the capital that goes to determine the overall state of liquidity. Based on that perception, researchers have used changes in the external or international exposure of banks in different reporting countries as indicators of trends in global liquidity (Fornari and Levy, 2000). Since the debt crisis, the Bank of International Settlements has encouraged banks located in different countries to report their international exposure through an official system, with institutions from 40 countries currently reporting. As noted earlier, the number of reporting countries has increased over time making the absolute figures incomparable. However, continuous figures are available from 1994 for 23 reporting countries.

When we examine these figures it becomes clear that there has been a sharp increase in global liquidity (as proxied by the international exposure of banks) in the period after 2002 (chart 3 ). Having touched a low of $\$ 716$ billion that year, the exchange rate-adjusted changes in the external asset positions of banks in these 23 countries registered a more than five-fold nominal increase to reach $\$ 3.6$ trillion in 2006. This compares with a previous peak of $\$ 1.3$ trillion recorded in 1997, at the time of the East Asian financial crisis. Obviously, with global liquidity increasing at this rate, liquidity in the countries in which these banks are located rose as well. They are not merely recipients of flows from banks located elsewhere, but the domestic exposure of banks tends to rise with their international exposure, even if the rise in cross-border inter-bank flows results in a higher ratio of such flows relative to the corresponding measure of domestic liquidity.

Experience from previous crises, especially the East Asian crisis of 1997, suggests that a rapid expansion of international liquidity results in an increase in the proportion of speculative positions taken by market participants and a decline in credit quality. In particular, increased cross-border flows can be accompanied by complex carry trades, with money flowing from locations, markets and instruments where returns are low to targets offering high returns. This can lead to speculative bubbles in one or more locations. In addition, cross-border flows increase the potential for "contagion" - the international transmission of the effects of financial instability.

For example, apropos 1997, a Bank of Italy study found: "In the period between 1995 and 1997, global interbank activity expanded rapidly, characterized ... by net outflows from Japan. During this 
EXCHANGE RATE ADJUSTED CHANGES IN EXTERNAL POSITIONS OF BANKS IN 23 COUNTRIES, 1994-2006

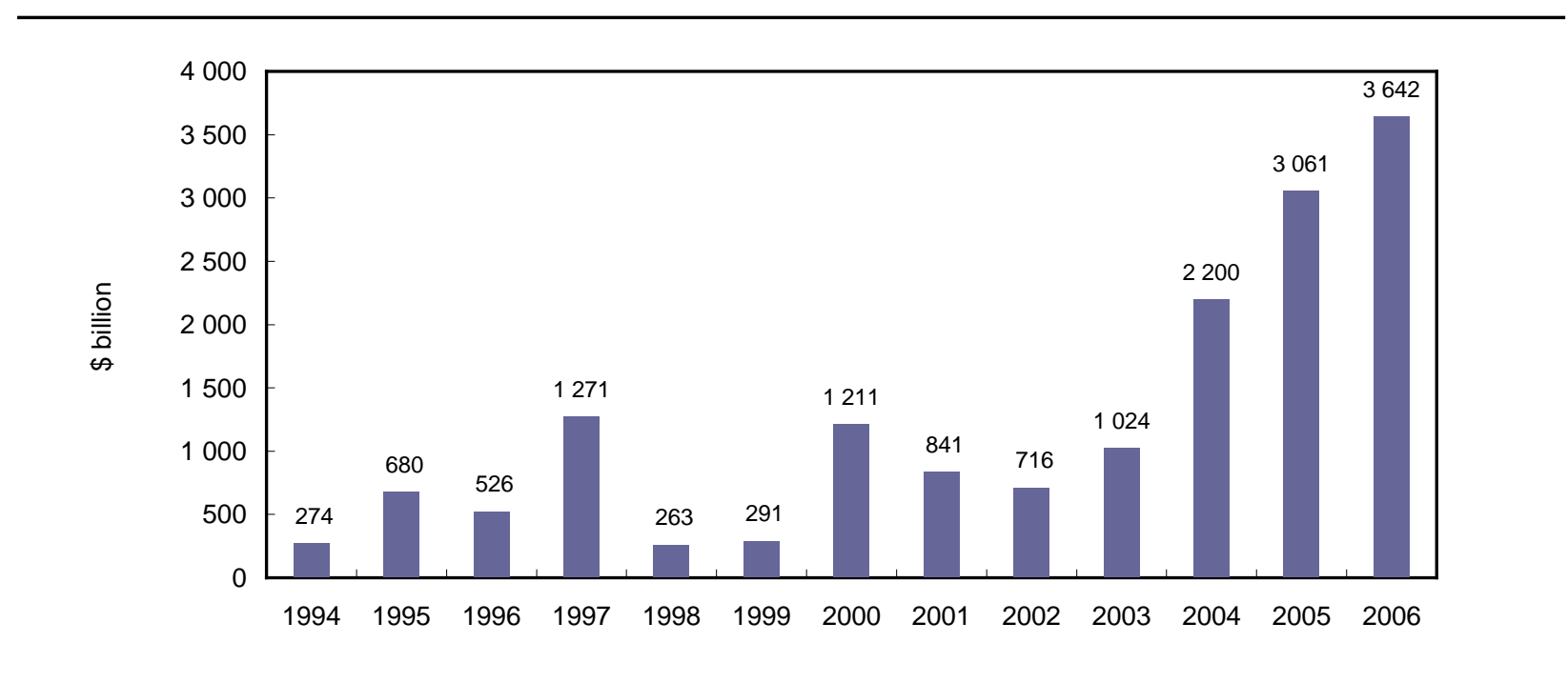

Source: Bank of International Settlements, BIS Quarterly Review: International Banking and Financial Market Developments, BIS Reporting Banks: Summary of International Positions, various issues. Available at: http://www.bis.org/publ/quarterly.htm.

period, the banking system of the industrial countries (excluding Japan) played the role of intermediary in the reallocation of flows, having made loans to offshore centres that were nearly equal to fund-raising from Japan (\$50 billion). The flows to emerging economies were enormous: $\$ 150$ billion to banks and $\$ 130$ billion to non-bank agents. Large capital flows (around \$100 billion) were recorded in favour of non-bank agents located in offshore centres, among which some non-bank financial intermediaries such as hedge funds are also probably included" (Fornari and Levy, 2000: 2).

There is reason to believe that similar developments occurred in the course of the more recent liquidity surge. Between June 2003 and June 2007, total foreign claims of banks in all reporting countries increased by 112 per cent with respect to developed countries, 102 per cent with respect to offshore centres and 163 per cent with respect to developing countries (table 2). There is a high degree of concentration of flows to emerging markets in Europe and Asia-Pacific. Flows to offshore centres and developing countries from different developed country locations increased by between 100 and 240 per cent over this four year period. This implies that though instability currently characterizes the market for mortgage loans and mortgage-backed securities, the problems created by excessive liquidity expansion affects all favoured investment locations including developing countries in Europe and Asia.

Not surprisingly, in the recent surge of capital flows to developing countries, almost all emerging markets, especially those in Europe and Asia have experienced increased inflows, with attendant buoyancy in their stock and real estate markets. These inflows have implied the accumulation of larger speculative positions by many investors, including highly leveraged ones. One possible indicator of that tendency is that, while the outstanding values of all kinds of international assets held by banks doubled during the recent surge (2003-2007), derivative contracts, especially over the counter, have increased by much more (table 3 ).

What this suggests is that the problems arising from the sub-prime mortgage crisis and the collateralized debt obligations associated with sub-prime loans reflects the unravelling of only one set of problems created by the liquidity spiral of recent years. Another, which could have unravelled and 
Table 2

PERCENTAGE INCREASE IN EXPOSURE TO DIFFERENT LOCATIONS

BY NATIONALITY OF BANKS, 2003-2007

\begin{tabular}{lcrccc}
\hline Claims vis-à-vis & Total foreign claims & Japan & United Kingdom & United States & Other \\
\hline All countries & 115.5 & 65.9 & 122.1 & 118.1 & 119.8 \\
Developed countries & 112.0 & 54.8 & 122.0 & 116.0 & 116.4 \\
Offshore centres & 102.2 & 105.4 & 69.8 & 150.0 & 110.1 \\
Developing countries & 163.2 & 118.7 & 240.5 & 114.0 & 165.1 \\
Africa and Middle East & 154.6 & 88.5 & 399.7 & 164.0 & 98.1 \\
Asia and Pacific & 181.2 & 111.2 & 244.2 & 204.4 & 169.6 \\
Europe & 267.9 & 392.4 & 251.3 & 192.8 & 271.9 \\
Latin America/Caribbean & 74.0 & 74.9 & 108.6 & 39.1 & 82.3 \\
International organizations & -13.7 &.. & -71.7 &.. & 42.3 \\
Unallocated & -61.0 &.. & -70.1 &.. & -60.9 \\
\hline
\end{tabular}

Source: Computed from data available in Bank of International Settlements, BIS Quarterly Review: International Banking and Financial Market Developments, BIS Reporting Banks: Summary of International Positions, various issues. Available at: http://www.bis.org/publ/quarterly.htm.

Table 3

\section{CHANGES IN OUTSTANDING POSITIONS FOR KEY INTERNATIONAL FINANCIAL ASSETS}

(Billions of dollars)

\begin{tabular}{lrr}
\hline & June 2007 & June 2003 \\
\hline $\begin{array}{l}\text { Total external asset positions } \\
\text { of banks }\end{array}$ & 29980.5 & 14853.8 \\
$\quad$ Claims on banks & 19094.6 & 9663.6 \\
$\quad$ Claims on non banks & 10886.0 & 5190.2 \\
External Loans & 21920.0 & 11130.7 \\
International debt securities & 20878.3 & 10268.7 \\
International money market & & \\
instruments & 1114.3 & 519.3 \\
International bonds and notes & 19764.0 & 9749.5 \\
$\begin{array}{l}\text { OTC derivatives } \\
\text { (notional value) }\end{array}$ & 513407.0 & 169678.0 \\
Exchange-traded derivatives & & \\
$\quad \begin{array}{l}\text { Futures } \\
\text { Options }\end{array}$ & 31676.9 & 13930.5 \\
\hline
\end{tabular}

Source: Bank of International Settlements, BIS Quarterly Review: International Banking and Financial Market Developments, BIS Reporting Banks: Summary of International Positions, December 2003; December 2007. Available at: http://www.bis.org/publ/quarterly.htm. can still unravel is the excessive exposure, encouraged by excess liquidity, of international investors and lenders in a few developing countries and the securitized assets built on that exposure. That is, a supply-side push of capital into the stock, credit and real estate markets in emerging market economies could have created a second source of fragility in the international financial system besides the United States sub-prime mortgage market.

This is of significance because the lesson from the sub-prime loan crisis is that when suspect loans result in payments defaults, those loan assets and the securitized obligations that have been built on them become suspect as well, resulting in a drying up of demand for such assets. Holders of such assets who want to sell, even if at a loss, to meet commitments that fall due, find there are no takers, so that a financial world, that was till recently awash with liquidity suddenly turns illiquid. This has happened with only one segment of the market experiencing a doubtful loan or investment problem. If the build-up of speculative positions in other markets associated with the recent surge in liquidity generates new problem loans and investments, the transformation from liquidity excess to liquidity squeeze may be far too severe for central bankers and governments to resolve without much damage. 


\section{B. Determinants of liquidity movements}

What needs investigating, therefore, is the set of factors that led to the liquidity build up in the first place. One factor is, of course a sudden accumulation of foreign exchange surpluses with a few countries and firms, resulting from the increase in oil prices, for example. With these oil surpluses looking for investment opportunities finding their way to financial markets, an excess liquidity syndrome may result. In fact, there is a close association between oil price movements and the build-up of global liquidity in recent years (chart 4). But this is only one fortuitous development contributing to liquidity. Moreover, since speculation touches commodities as well, the direction of causation also moves from liquidity to oil prices, as it does the other way around.

There are three other factors that could have played a role in influencing the level of liquidity. The first is the long term tendency inherent in the dynamic of the contemporary global system for an increase in liquidity. The liquidity that drives the supply-side push of capital to emerging markets originates in the transformation of capitalism that has occurred under the tutelage of neoconservative ideologies. The growing inequality characterizing an unregulated capitalism, in which wages stagnate while productivity and profits rise, has resulted in the accumulation of vast sums of capital in the hands of a few investors in the metropolitan centres of global capitalism. ${ }^{3}$ These gains are lightly taxed by governments that are not committed to appropriating a part of the surpluses of the rich to improve the welfare of the poor. Lower down the ladder, investment capital accumulates with mutual and pension funds in which less protected populations deposit the savings they put aside to insure their future. The decline of state-funded welfare in today's more liberalized and open capitalism is forcing the middle classes in the developed countries to save by subscribing to these funds that have become important sources of financial capital. Financial firms in developed countries leverage capital from these sources by borrowing huge sums to invest, increasingly in high-risk, high-return speculative investments.

A second reason for the liquidity build-up noted by many observers is a tendency in recent years for developed country central banks to adopt an easy money policy, aimed at encouraging creditfinanced spending in housing and consumer goods markets, that keeps consumer demand buoyant and

Chart 4

GLOBAL LIQUIDITY AND OIL PRICES, 1994-2006

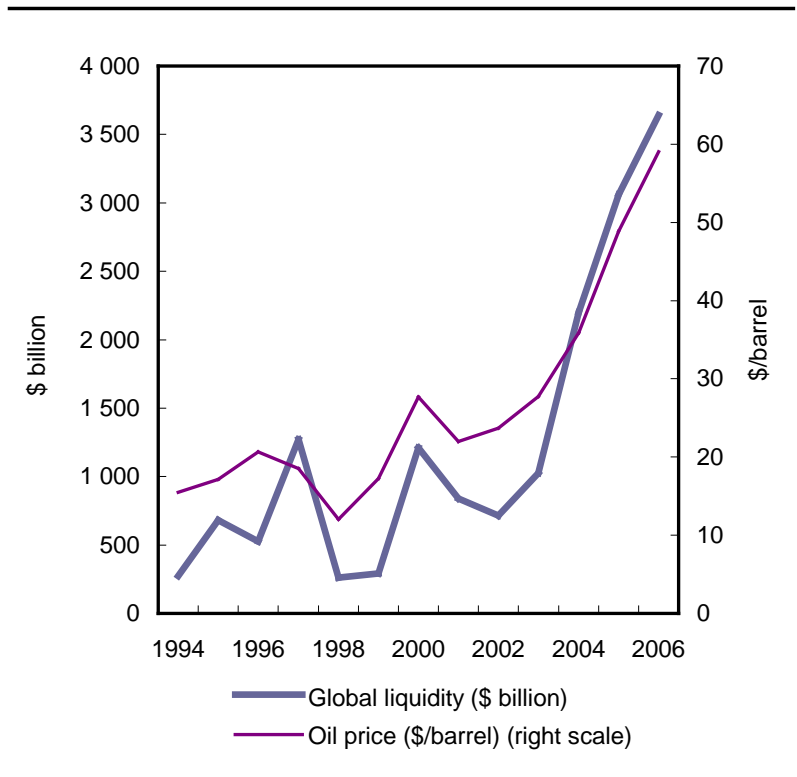

Source: Global liquidity figures from source quoted in chart 3. Oil prices from U.S. Energy Information Administration. Available at: http://tonto.eia.doe.gov/dnav/pet/ hist/r1300 3a.htm. Accessed 20 December 2007.

GDP growth at "acceptable" levels. Considering the United States, which is at the centre of the global financial system, while the relationship between formal measures of the United States money supply (M3 to GDP ratio) and the global liquidity index is not perfect, there does appear to be a significantly strong positive relation between the United States domestic monetary conditions and global liquidity in recent years (chart 5).

Third, developing countries adversely affected or threatened by the financial crises of 1997-1998 have since been more cautious about the use of foreign exchange. In most cases, this has involved maintaining investment rates below domestic savings rates to generate current account surpluses in the balance of payments, or, in the face of current account deficits, making sure that not all net capital inflows were exhausted through current or capital expenditures. The result has been a huge build up in foreign exchange surpluses in developing countries which, in myriad ways, find their way to financial centres in the developed countries, only to partly return as investments in emerging markets. That is, the crisis 


\section{Chart 5}

\section{GLOBAL LIQUIDITY AND RATIO OF M3 TO} GDP IN THE UNITED STATES, 1994-2005

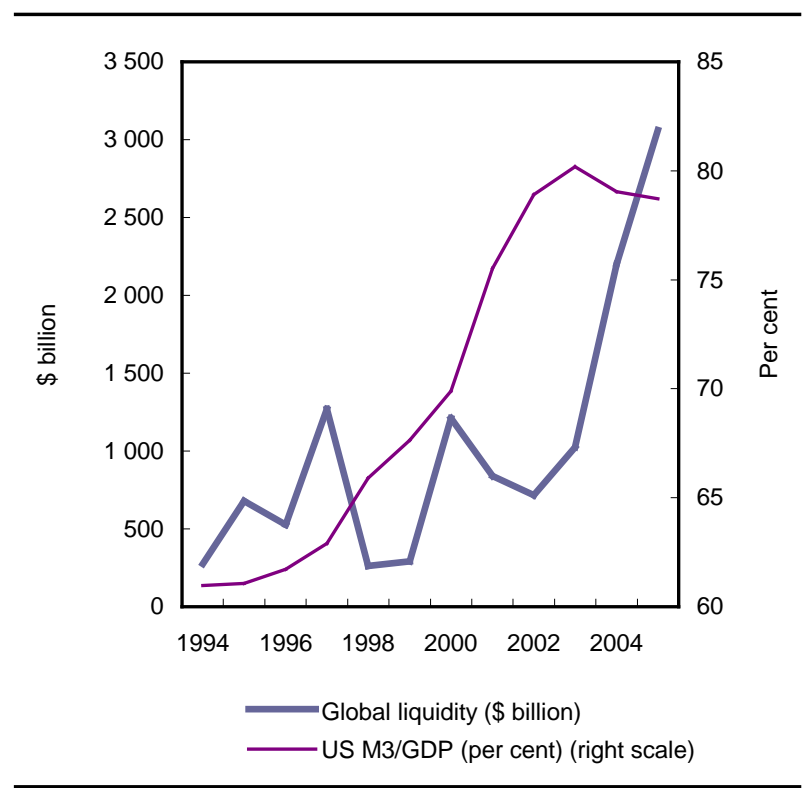

Source: Global liquidity figures from source quoted in chart 3. US monetary aggregate M3 from US Federal Reserve Board. Available at http://www.federalreserve.gov/ releases/h6/HIST/h6hista.pdf. Accessed 20 December 2007. (The Federal Reserve discontinued issue of M3 figures as of 23 March 2006.)

\section{Chart 6}

\section{GLOBAL LIQUIDITY AND GLOBAL RESERVES, 1994-2006}

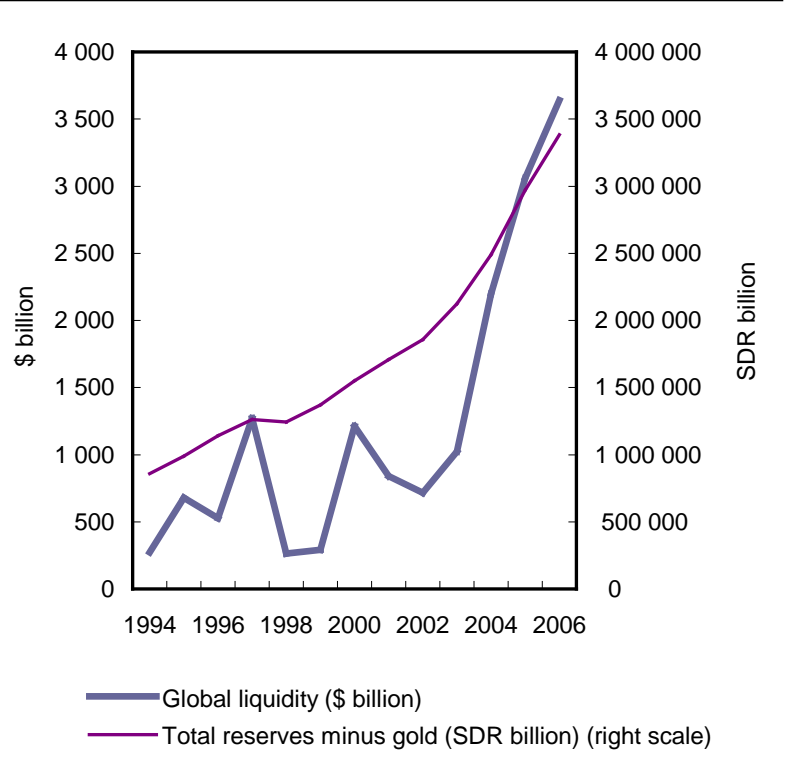

Source: Global liquidity figures from source quoted in chart 3 . Global Reserves (excluding gold) figures from IMF, International Financial Statistics Online. generated by excess liquidity in the past results in an environment that contributes to a new round of liquidity accumulation. Chart 6 tracks the relationship between global reserves and global liquidity, and shows a strong relationship between the two.

This reverse flow of capital essentially means that excess savings in emerging markets are being "recycled" in ways that puts the responsibility of allocating that capital in the hands of a few financial decision makers at the apex of a concentrated global financial system. For example, according to reports, in the wake of China's decision to invest part of its foreign exchange surpluses in funds managed by the Blackstone (private equity) group, much of this capital flowed back as investment into firms located in China itself, feeding a spiral that leaves the problem of large surpluses unresolved. More recently, much has been made of the rise of sovereign wealth funds in developing countries, epitomized by the China Investment Corporation (CIC), that are seen as a challenge to financial institutions from the developed countries, especially the United States and the United Kingdom, which have traditionally dominated global finance. However, a significant part of the investments by these sovereign wealth funds is in global financial intermediaries or the funds they manage.

\section{Consequences of supply-side capital flow pressures}

When liquidity accumulates in the international financial system, financial firms are not only under pressure to keep money moving to earn returns from spreads, but also to "innovate" in order to profit from the situation of excess liquidity in the more liberalized financial environment of today. One consequence of the desire to keep money moving is that, at different points in time, one or another group of developing countries is discovered as a "favourable" destination for foreign financial investors. Increased competition and falling returns in the developed countries are also encouraging financial firms to seek out new opportunities in emerging markets. This supply side push translates into an actual flow only when developing countries as a group, including the "emerging markets" among them, relax controls on inflows of capital and the repatriation of profits and investments as well as liberalize their financial systems to attract international players and accommodate their operating strategies. In practice, despite the East Asian 
crisis and similar crises in other parts of the world, and the evidence that these crises resulted from more open capital accounts, developing countries have competed with one another to attract such inflows by opting for international financial liberalization.

\section{New trends in capital flows to developing countries}

Overall, the willingness to accommodate supply-side pressures has had rather dramatic implications for capital flows to developing countries. The first of these is an acceleration of financial flows to developing countries precisely during the years when as a group they have been characterized by rising current account surpluses. Total flows reached a record $\$ 571$ billion in 2006 , having risen by 19 per cent after an average growth of 40 per cent during the previous three years. Relative to the GDP of these countries, total flows, at 5.1 per cent, are at levels reached at the time of the East Asian financial crisis in 1997-1998 (figures in this section are from World Bank, 2007).

A second feature is the acceleration of the long term tendency for private flows to dominate official (bilateral and multilateral) flows. Private debt and equity inflows, which had risen by 50 per cent annually over the three years ending 2005, increased a further 17 per cent in 2006 to reach a record $\$ 647$ billion. On the other hand, net official lending has, in fact, declined over the last two years, partly because some developing countries have chosen to make advance repayments of debt owed to official creditors, especially the IMF and the World Bank (WB). Once flows between private lenders and borrowers or private investors and firms dominate, the implicit sovereign guarantees associated with lending to governments or providing government guaranteed credits no longer exist, increasing the probability of default.

Third, after a period following the 1997-1998 crisis when debt flows almost dried up, both equity and debt flows to developing countries have risen rapidly in recent years. Net private debt and equity flows to developing countries have risen from a little less than $\$ 170$ billion in 2002 to close to $\$ 647$ billion in 2006, an almost four-fold increase over a four-year period. While net private equity flows, which rose from $\$ 163$ billion to $\$ 419$ billion, dominated the surge, net private debt flows also increased rapidly.
Bond issues rose from $\$ 10.4$ billion to $\$ 49.3$ billion, and borrowing from international banks from $\$ 2.3$ billion to a huge $\$ 112.2$ billion. What is more, net short-term debt, outflows of which tend to trigger financial crises, rose from around half a billion in 2002 to $\$ 72$ billion in 2006 . According to the BIS statistics, syndicated loan agreements signed by developing country borrowers rose after the immediate post-1997 slump, from $\$ 6.9$ billion in 2002 to $\$ 237.9$ billion in 2006 , which compares with the previous peak of \$129.2 billion in 1997.

The fourth feature, a corollary of these developments, is the high degree of concentration of flows to developing countries, implying excessive exposure in a few countries. Ten countries (out of 135) accounted for 60 per cent of all borrowing during 2002-2004, and that proportion has risen subsequently to threequarters in 2006. In the portfolio equity market, flows to developing countries were directed at acquiring a share in equity either through the secondary market or by buying into initial public offers (IPOs). IPOs dominated in 2006, accounting for $\$ 53$ billion of the $\$ 96$ billion in inflows. But here too, there were signs of concentration. Four of the 10 largest IPOs were by the Chinese companies, accounting for two-thirds of total IPO value. Another 3 of the 10 were by the Russian companies, accounting for an additional 22 per cent of total IPO value.

Finally, despite this rapid rise in developing country exposure, with the exposure highly concentrated in a few countries, the market is still overtly optimistic. Ratings upgrades dominate downgrades in the bond market. And bond market spreads are at unusual lows. This optimism indicates that risk assessments are pro-cyclical, underestimating risk when investments are booming, and exaggerating risks when markets turn downwards. But two consequences are the herd behaviour of investors in developing country markets and their willingness to invest a larger volume of money in risky, unrated instruments.

In sum, we are now witnessing a return to a period when large and rising inflows, herd behaviour and over exposure have come to characterize capital flows from the North to the South. Is there reason to believe that - unlike in 1997, say - this time around, these developments are benign, or even positive, from the point of view of the developing countries, as some would suggest? Besides the many crises that have occurred across the developing world, including in 
Argentina and Turkey, during the decade since 1997, structural changes in the global financial system suggest that risk, including systemic risk, has only increased. And the experience with the sub-prime mortgage crisis suggests that even in developed countries, the regulatory framework has not evolved to match the complexity of markets, institutions and instruments that characterize today's financial systems, and prudential regulation, new disclosure norms and changed accounting practices have not been successful in identifying fragility before it is too late.

\section{A. Structural transformation of global finance}

This experience matters because of evidence that the rapid rise of capital flows to developing countries has been associated with the increasing dominance of the global financial architecture by a few institutions, which are present in almost all countries. During the 1990s, the three-decade long process of proliferation and rise to dominance of finance in the global economy reached a new phase. Financial consolidation saw greater concentration of financial activity and decision making in a few organizations. And financial integration joined hitherto demarcated areas of financial activity that had been dissociated from each other to ensure transparency, check conflicts of interest and discourage unsound financial practices.

A study (Group of 10, 2001) of financial consolidation commissioned by finance ministers and central bank governors of the Group of 10 found, as expected, a high level of merger and acquisition (M\&A) activity in the study countries during the 1990s, with an acceleration of such activity in the last three years of that decade. The number of acquisitions by financial firms from the survey countries increased from around 337 in 1990 to between 900 and 1000 by the end of the decade. Further, the average value of each of these acquisitions increased from \$224 million in 1990 to $\$ 649$ million in 1999 . Clearly, M\&As in the financial sector were creating large and complex financial organizations in the international financial system.

Further, over the 1990s as a whole the evidence seems to be that M\&A activity was largely industry-specific, with banking firms tending to merge dominantly with other banks. However, the pattern was changing over time. While in 1994 there was one instance of cross-industry M\&A for every five instances of intra-industry mergers, the ratio had come down to one in every three by 1999 . The mergers and acquisitions drive within the financial sector was not merely creating large and powerful organizations, but firms that increasingly straddled the financial sector. Exploiting the process of financial liberalization, these firms were breaking down the Chinese walls that had been built between different segments of the financial sector.

With growing financial liberalization in the developing world, it was inevitable that this process would affect developing countries as well. According to a study by the Committee on the Global Financial System (CGFS, 2004), there has been a surge in foreign direct investment in the financial sectors of developing countries. The study, by using crossborder M\&As targeting banks in emerging market economies (EMEs), found that cross-border deals involving financial institutions from EMEs as targets, which accounted for 18 per cent of such M\&A deals worldwide during 1990-1996, rose to 30 per cent during 1997-2000. The value of financial sector FDI rose from about \$6 billion during 1990-1996 to $\$ 50$ billion during the next four years. Such FDI peaked at $\$ 20$ billion in 2001, declined sharply in 2002 , but stabilized in 2003. The net result is a clear shift in the ownership of the financial sector (table 4). Anecdotal evidence indicates that this figure has risen sharply since.

With respect to Asia, CGFS found that: "The proportion of cross-border M\&As in East Asia's financial sector initially was small compared with other regions. The value of cross-border M\&As targeting non-Japan Asian countries was $\$ 14$ billion or $17 \%$ of the total during 1990-2003. Asia, however, has been one of the fastest growing target regions for M\&A, with a sizeable jump in cross-border M\&A activity occurring in Korea and Thailand. In addition, there has been a large number of small-value cross-border M\&A transactions in the finance sector between East Asian economies. In 2003, Asia received the largest share of FSFDI inflows."

Besides liberalization and the high returns in hitherto protected financial markets, financial crises also favoured globalization. As the CGFS study notes: "A standard response to crises by EME governments, encouraged by the international financial 
Table 4

OWNERSHIP STRUCTURE IN THE BANKING SYSTEMS OF EMERGING MARKET ECONOMIES ${ }^{a}$

\begin{tabular}{|c|c|c|c|c|c|c|}
\hline & \multicolumn{3}{|c|}{1990} & \multicolumn{3}{|c|}{$2002^{b}$} \\
\hline & \multicolumn{2}{|c|}{ Domestic } & \multirow[t]{2}{*}{ Foreign } & \multicolumn{2}{|c|}{ Domestic } & \multirow[t]{2}{*}{ Foreign } \\
\hline & Private $^{c}$ & Government & & Private & Government & \\
\hline \multicolumn{7}{|l|}{ Asia } \\
\hline China & 0 & 100 & 0 & & 98 & $2^{d}$ \\
\hline Hong Kong, China & 11 & 0 & 89 & & 28 & 72 \\
\hline Indonesia & .. & .. & 4 & 37 & 51 & 13 \\
\hline India & 4 & 91 & 5 & 12 & 80 & 8 \\
\hline Korea, Republic of & 75 & 21 & 4 & 62 & 30 & 8 \\
\hline Malaysia & .. & .. & .. & & 72 & 18 \\
\hline Philippines & 84 & 7 & 9 & 70 & 12 & 18 \\
\hline Singapore & 11 & 0 & 89 & 24 & 0 & 76 \\
\hline Thailand & 82 & 13 & 5 & 51 & 31 & 18 \\
\hline \multicolumn{7}{|l|}{ Latin America } \\
\hline Argentina & .. & $36^{e}$ & $10^{f}$ & 19 & 33 & 48 \\
\hline Brazil & 30 & 64 & 6 & 27 & 46 & 27 \\
\hline Chile & 62 & 19 & 19 & 46 & 13 & 42 \\
\hline Mexico & 1 & 97 & 2 & 18 & 0 & 82 \\
\hline Peru & 41 & 55 & 4 & 43 & 11 & 46 \\
\hline Venezuela & 93 & $6^{g}$ & $1^{g}$ & 39 & 27 & 34 \\
\hline \multicolumn{7}{|c|}{ Central and Eastern Europe } \\
\hline Bulgaria & .. & .. & 0 & 20 & 13 & 67 \\
\hline Czech Republic & $12^{e}$ & $78^{e}$ & $10^{e}$ & 14 & 4 & 82 \\
\hline Estonia &.. &.. &.. & 1 & 0 & 99 \\
\hline Hungary & 9 & 81 & 10 & 11 & 27 & 62 \\
\hline Poland & $17^{g}$ & $80^{g}$ & $3^{g}$ & 10 & 17 & 63 \\
\hline Russian Federation &.. &.. & 6 & 23 & 68 & 9 \\
\hline Slovakia &.. & .. & 0 & 9 & 5 & 85 \\
\hline
\end{tabular}

Source: Committee on the Global Financial System, 2004, table 1, page 9.

a Percentage share of total bank assets. 2002 figures for Central and Eastern Europe: percentage share of regulatory capital.

b Data are shown for the latest year available, which is mainly 2002.

c Calculated as residual.

d 1999.

e 1994.

f Average of 1988-1993.

g 1993.

.. Not available.

institutions, was to accelerate financial liberalization and to recapitalize banks with the help of foreign investors. This was the case in Latin America in the years following the 1994 Mexican crisis." In Asia also, most governments liberalized the terms of foreign entry and ownership after the crisis, but the major role played by governments in the recapitalization of banks delayed the expansion of foreign presence.
Thus, the global financial system is clearly characterized by a high degree of centralization. With the United States financial institutions intermediating global capital flows, the investment decisions of a few individuals in a few institutions virtually determines the nature of the "exposure" of the global financial system. The growing presence of a few consolidated global players in the developing countries has implications for the accumulation of risk in markets 
where agents tend to herd. Unfortunately, unregulated entities making huge profits on highly speculative investments are at the core of that system.

\section{B. Hedge funds and private equity firms}

Liberalization has not just increased consolidation and the global integration of the banking industry in developing countries. Many are now home to the activities of institutions like hedge funds and private equity firms that are loosely regulated in the developed countries, highly leveraged and pursue unconventional, speculative and risky investment strategies in relatively illiquid assets aimed at exploiting mispricing and arbitrage opportunities to ensure high returns for their investors. With investment banks and fund managers adopting practices similar to these entities, the distinction between these and other financial institutions is blurring at the level of activity, except perhaps for the concentration of the activities of these entities on specific kinds of trades.

While controversial for long, hedge funds gained notoriety in 1992 when George Soros' Quantum Fund was held responsible for the speculative attack on the British pound, and in the late 1990s, with the collapse of the much publicized Long Term Capital Management (LTCM) with its star traders, Nobel-winning economists and high-return track record. For developing countries, their notoriety was linked to their alleged role in the currency speculation that precipitated the 1997-1998 crisis.

Yet, hedge fund activity in developing countries has increased substantially in recent years, including in Asia. Encouraged by liberalization, that ensures not only entry, but the proliferation of instruments, the growth of derivatives markets, the emergence of futures, and the increase in "shorting" possibilities, these firms have devoted much attention to these markets. According to one estimate quoted by the Financial Stability Forum (2007), the share of hedge fund assets managed in Asia has risen from 5 per cent in 2002 to 8 per cent in 2006. These increases have been at the expense of the United States, which while recording a significant increase in hedge fund activity in absolute terms, has seen a decline in its share of the global total from more than 80 per cent in 2002 to about 65 per cent in 2006.
Besides hedge funds, portfolio diversification by financial investors in developed countries seeking new targets, higher returns and/or hedges has, over the last quarter of a century, seen a revival of private equity firms. Private equity, as originally broadly defined, involves investment in equity linked to an asset not listed and therefore not publicly traded in stock markets. Given this broad definition, a range of transactions and/or assets fall under its purview, including venture capital investments, leveraged buyouts and mezzanine debt financing, where the creditor expects to gain from the appreciation in equity value by exploiting conversion features such as rights, warrants or options.

While private equity has been growing rapidly, its activities in developed countries is being curbed by growing opposition to these firms and their activities. A major criticism of private equity firms is their lack of transparency. Besides, they are being accused of wielding the hatchet against workers or breaking up companies by restructuring firms.

One result of all this is that private equity firms are finding it harder to conduct business in the United States and Europe. Not surprisingly, the business is increasingly moving overseas, especially to emerging market countries where markets are booming because of foreign institutional investment inflows.

According to the Emerging Markets Private Equity Association (EMPEA, 2006), fundraising for emerging market private equity surged in 2005 and 2006. Estimated at $\$ 3.4$ billion in 2003 and $\$ 5.8$ billion in 2004 , the figure shot up to $\$ 22.1$ billion in 2004 and $\$ 21.9$ billion in the period to 1 November during 2006. Asia (excluding Australia, Japan and New Zealand) dominated the surge, with the figure rising from $\$ 2.2$ billion in 2003 and $\$ 2.8$ billion in 2004 to $\$ 15.4$ billion in 2005 and $\$ 14.5$ billion during the first ten months of 2006.

Deal-making in developing countries has also gained momentum. Dealogic estimates (Metrics 2.0, 2006) that the value of private equity deals in the Asia Pacific, excluding Japan, more than tripled to \$26 billion in 2006 from $\$ 7$ billion in 2005. Private equity buyouts have accounted for 7 per cent of regional merger and acquisition volume in 2006, up from 3 per cent in 2005, but still below the global figure of 17 per cent. While Australia accounted for $\$ 11.7$ billion in activity, deals in the Indian sub-continent jumped to $\$ 3.1$ billion in 2006 from $\$ 764$ million in 2005 , 
with Kohlberg Kravis Roberts \& Co.’s \$900 million purchase of Flextronics Software Systems, India's largest deal. East Asia deals totalled \$10.4 billion, led by Goldman Sachs' $\$ 2.6$ billion investment in Industrial and Commercial Bank of China, 2007's biggest regional deal. Investment banks raked in \$304 million in net revenue from private equity investors in 2006 , compared with \$239 million in 2005.

\section{Transformation of the financial sector}

The increased foreign presence in the financial sector in developing countries has meant that capital flows are accompanied by the movement of firms and institutions from developed to developing countries. Countries wanting to attract financial investments have to accommodate financial investors as well. Further, when these entities are permitted to enter developing country markets, they would want to replicate their business practices in the new environment. Policies of financial liberalization are, inter alia, meant to meet these requirements of finance capital in countries seeking to attract financial investments. Financial liberalization therefore: (i) opens the country to new forms and larger volumes of international financial flows; (ii) allows entry of foreign financial entities, varying from banks to private equity firms, into the country; and (iii) dilutes or dismantles regulations and controls the operations of financial entities and the pursuit of their preferred practices. A consequence of such liberalization is financial consolidation and the proliferation of new institutions and instruments. It has been argued for some time now, especially since the East Asian crisis, that financial liberalization, involving liberalization of controls on inflows and outflows of capital respectively, has increased financial fragility in developing countries, making them more vulnerable to periodic financial and currency crises.

Analyses of individual instances of crises have tended to conclude that the nature and timing of these crises have had much to do with the shift to a more liberal and open financial regime. What is less emphasized is the vulnerability that stems from the proliferation of new kinds of foreign institutions, new instruments and new business practices in the wake of liberalization. The increased extent of liberalization over the last decade has not only led to the surge in capital flows in recent years, but also encouraged the entry of speculative investors adopting unusual lending and investment practices in environments even less regulated than the United States. This would, therefore, have substantially increased, rather than reduced, financial vulnerability over the last decade.

\section{Lessons from the United States sub-prime crisis}

The United States sub-prime mortgage crisis illustrates how underlying such vulnerability is the financial entanglement which results from the layered financial structure, "innovative" financial products and inadequate financial regulation associated with the increasingly liberalized and globalized financial system in most countries. Few would deny that the source of the crisis in the sub-prime housing loan market in the United States - consisting of loans to borrowers with a poor credit record - is the way in which the preceding housing market and consumption booms were triggered and sustained. Housing demand grew rapidly because of easy access to credit, with credit extended to borrowers considered less than creditworthy. These sub-prime borrowers were offered credit at higher rates of interest, made attractive by special offers and unusual financing arrangements - with little documentation or selfcertification of income, little or no down payment, extended repayment periods and structured payment schedules involving low interest rates in the initial phases which were "adjustable" and moved sharply upwards when "reset" to reflect premia on market interest rates. All this encouraged high-risk borrowers to take on loans they could ill understand, let alone afford, either because they did not fully understand the payment burdens they were taking on, expected to profit from the booming property market, or expected their incomes to rise sufficiently to cope with their new debt burden. Clearly, the problem is largely a supply-side creation driven by factors such as easy liquidity, low interest rates and "debt-pushing" efforts by lending institutions competing for new business. In these circumstances, mortgage brokers attracted clients by relaxing income documentation requirements or offering early grace periods with low or no payments, after which higher rates would kick in. As a result, the share of such sub-prime loans in all mortgages rose sharply. Estimates vary, but according to Inside Mortgage Finance quoted by the New York Times (Creswell and Bajaj, 2007), sub-prime loans reached $\$ 600$ billion in 2006 , or 20 per cent of the mortgage loan total as compared with just 5 per cent in 2001 . 
The increase in this type of credit occurred because of the complex nature of current-day finance that allows an array of agents to earn lucrative returns, even while transferring the risk associated with the investments that offer these returns. Mortgage brokers seek out and find willing borrowers for a fee, taking on excessive risk while in search of volume. Mortgage lenders finance these mortgages, not with the intention of actually garnering the interest and amortization flows associated with such lending, but in order to sell on these mortgages to Wall Street banks and other investors in collateralized securities. The Wall Street banks buy these mortgages because they can bundle assets with varying returns to create securities or collateralized debt obligations, involving tranches with differing probabilities of default and differential protection against losses. They charge hefty fees for structuring these products and having them rated with complex mathematical models, before selling them to a range of investors such as banks, mutual funds, pension funds and insurance companies. These entities in turn, can then create a portfolio involving varying degrees of risk and different streams of future cash flows linked to the original mortgages. Firms like the unregulated hedge funds make speculative investments in derivatives of various kinds in search of high returns for their high net worth investors. Needless to say, institutions at every level are not fully devoid of risk, but these risks are shared and rest in large measure with the final investors in the chain.

This structure is relatively stable so long as defaults are a small proportion of the total. But if the proportion of defaults increases, as the share of subprime mortgages in the total rises, the bottom of the barrel gives, and all assets become less liquid. Rising foreclosures adversely affect property prices and saleability as foreclosed assets are put up for sale as credit is squeezed because lenders turn wary. And securities built on these mortgages turn illiquid because there are few buyers for assets whose values are opaque since there is no ready market for them. Consequently, for example, a leading Wall Street bank like Bear Stearns has to declare that investments in two funds it created linked to mortgage-backed securities were worthless. The investors themselves have to sell-off other assets to rebalance their portfolios, sending ripples into markets such as those in developing countries that have little to do with the United States sub-prime market.

The problem is not restricted to the Wall Street banks. For example, in early August 2007, the French bank BNP Paribas suspended withdrawals from three of its funds exposed to the mortgage-backed securities market. The bank reportedly attributed its decision to "the complete evaporation of liquidity in certain market segments", which constrained it from meeting withdrawal demands that could have turned into a run on the fund. In some cases, a bail-out became necessary, as was true of the Düsseldorf-based Deutsche Industriebank AG (IKB), which, through offshore front company Rhineland Funding, had invested as much as $\$ 17.5$ billion in asset-backed securities. As the value of its assets fell, Rhineland had to call on $\mathrm{a} € 12$ billion line of credit that it had negotiated with a group of banks, including Deutsche Bank, besides IKB itself. Deutsche Bank decided to opt out of its promise to lend, resulting in the discovery that the Fund had suffered huge losses and needed a bail-out led by state owned Kreditanstalt für Wiederaufbau (KfW). In the United Kingdom, Northern Rock, a top mortgage lending bank that began as a housing society, incurred losses in the sub-prime market and became the target of a bank run. Worried depositors began pulling out their money, forcing the Bank of England to intervene because of fears that the run would spread to other banks. In sum, the effects of the sub-prime crisis weakened distant segments of the global financial system, as a result of financial entanglement.

Entanglement also makes nonsense of the theory that a complex financial system with multiple institutions, securitization, proliferating instruments and global reach is safer because it spreads risk. This is illustrated by the example of IKB referred to above. Banks wanting to reduce the risk they carry resort to securitization to transfer this risk. But institutions created by the banks themselves, linked to them in today's more universalized banking system or leveraged with bank finance, often buy the very instruments created to transfer risk. In the event, as The Economist ("Prime Movers" 11 August 2007) put it, "banks (that) have shown risk out of the front door by selling loans, only ... let it return through the back door." This, it notes, is exactly what transpires in the relationship between the three major Wall Street firms - Goldman Sachs, Morgan Stanley and Bear Sterns - that offer prime broking services, including loans, to highly leveraged institutions like hedge funds. The bail-out of LTCM in 1998 was necessitated because of such entanglement involving all the leading merchant (investment) banks.

Investments by banks, pension funds and mutual funds have been increasingly driven by the search for 
high and quick returns in a world of excess liquidity. In deciding to invest in structured products intermediated at different levels, these institutions, ill-equipped to judge the true value and risk of these assets, rely on rating agencies. But their ratings have turned out to be unreliable and pro-cyclical, serving as erroneous and pro-cyclically adjusted signals. Noting that "in a matter of weeks thousands of portions of subprime debt issued as recently as 2005 and 2006 have had their ratings slashed", The Economist ("Sold down the river Rhine", 11 August 2007) noted that investors should not have trusted the original ratings because "the rating agencies were earning huge fees for providing favourable judgments". What is more, even when there is no deception involved, rating agencies themselves are not well equipped to assess these products, and rely on information and models provided by the creators of the products themselves. Once an asset is rated, there is much reluctance to downgrade it, because it would raise doubts about related ratings and trigger sell-offs that may affect the prices of related securities that may in turn warrant further downgrades.

There are many lessons being driven home by the sub-prime mortgage crisis of particular significance for developing countries rapidly liberalizing their financial systems. First, easy liquidity in a loosely controlled financial system, which encourages the flow of capital to developing countries, facilitates speculative and unsound financial practices that increase fragility. Second, such practices are encouraged by the "financial innovation" that liberalization encourages, which often increases the layers of intermediation and allows firms to transfer risk. As a result, those who create risky "products" in the first instance are less exposed to or worried about the risk involved than they should be. Third, as the product moves up the financial chain, investors are less sure about the risk and value of these products than they should be, rendering even low risk, first-stage tranches prone to value loss. Fourth, this inadequate knowledge appears to be true even of the rating agencies on whose ratings investors rely, resulting in misleading and pro-cyclical ratings and belated adjustments. This implies that as and when a rating downgrade does occur, the asset becomes worth much less, since nobody is willing to buy the asset without large discounts. Fifth, new forms of self-regulation appear to be poor substitutes for more rigorous control, since the current crisis originates in a country whose financial sector is considered the most sophisticated, well regulated and transparent and serves as a model for others reforming their financial sectors. And finally, financial globalization and entanglement imply that countries that have more open and integrated financial systems are more prone to contagion effects, even if the virus originates in remote locations and markets. These are lessons that must inform policy in these so-called emerging markets.

\section{Signs of vulnerability}

If a supply-side driven surge in liquidity increased vulnerability in the United States, it would be much more difficult for developing countries with even poorer regulatory systems seeking to emulate the Anglo-Saxon financial model not to be vulnerable. One obvious indicator of such an increase in vulnerability is the massive "boom" in their stock markets that emerging markets across the Asian region have been experiencing (see annex charts). Market observers, the financial media and a range of analysts agree that foreign investments have been an important force, even if not always the only one, driving markets to unprecedented heights.

There are a number of reasons why this trend exacerbates vulnerability. To start with, the spike in stock prices is usually sharp i.e. very temporary. Second, this boom is generalized and occurs independently of the relative economic performance of the country concerned. This not only implies that fundamentals do not have the prime role in determining the behaviour of markets, but also means that the danger of contagion is real. Third, this occurs both in countries where investors have burnt their fingers in 1997-1998 and in those where they did not.

A second indicator of vulnerability is the revival of the credit spiral, which underlay the East Asian crisis. It was undoubtedly true that in the years immediately following the crisis, the flow of private non-guaranteed debt to developing countries as a group fell until 2000 and registered a marginal decline in the subsequent two years to 2002 (table 5). With governments wanting to discourage debt-dependence, and creditors wary of lending any further, even public and publicly guaranteed debt from private creditors sharply declined during those years. But matters seem to have changed dramatically over the last four years. The flow of non-guaranteed debt from private sources into developing countries increased by 250 per cent over the four years ending 2006. Simultaneously, 
Table 5

PRIVATE CREDIT TO DEVELOPING COUNTRIES, 1998-2006

(Billions of dollars)

\begin{tabular}{rrrrrr}
\hline & Bonds & Banks & Others & Short-term & Total \\
\hline 1998 & 38.8 & 49.4 & -5.3 & -65.3 & 17.6 \\
1999 & 30.1 & -5.3 & -1.5 & -17.3 & 6.0 \\
2000 & 20.9 & -3.8 & -3.7 & -6.3 & 7.1 \\
2001 & 10.3 & 7.8 & -6.5 & -23.7 & -12.1 \\
2002 & 10.4 & 2.3 & -6.9 & 0.5 & 6.3 \\
2003 & 24.7 & 14.5 & -4.4 & 55.0 & 89.8 \\
2004 & 39.8 & 50.6 & -4.0 & 68.4 & 154.8 \\
2005 & 55.1 & 86.0 & -4.9 & 67.7 & 203.9 \\
$2006 e$ & 49.3 & 112.2 & -5.5 & 72.0 & 228.0 \\
\hline
\end{tabular}

Source: World Bank, 2007.

governments too seem to have overcome their fear of debt with public or publicly guaranteed debt from private creditors having risen by more than 150 per cent. In sum, creditors appear willing to lend, and debtors willing to borrow, resulting in an aggregate scenario that spells debt dependence of a much larger magnitude than before the 1997 crisis.

There has been some change in composition by source as well. While in the immediate aftermath of the 1997-1998 crisis, the relatively small inflow of debt was due to bond issues by developing countries, with bank credit contracting, in more recent years there has been a revival of bank credit. The corporate share of external debt has risen from less than one-fifth of the total in the late 1990s to more than half in 2006.

What is disturbing is the extreme concentration of these flows, with a growing and now substantial share of it flowing to Europe and Central Asia. In 2006, 57 per cent of flows of private non-guaranteed debt went to this region, while East Asia and the Pacific received 14 per cent, and Latin America and the Caribbean 19 per cent. Just 10 countries accounted for three-quarters of all borrowing in 2006, a sharp increase from the already high 60 per cent average during 2002-2004. What is more, the evidence points to a growing share of lending to banks in developing countries, interested in exploiting the lower interest rates in international - as opposed to domestic - markets. Loan commitments to the banking sector totalled $\$ 32$ billion in 2006, which exceeded commitments to the oil and gas sector, a traditional leader.

Finally, the World Bank Global Development Finance 2007 noted a decline in credit quality accompanying these developments. To quote: "As private debt flows swell, riskier borrowers may be taking a larger share of the market. The share of bonds issued by unrated (sovereign and corporate) borrowers rose from 10 percent in 2000 to 37 percent in 2006, and the share of unsecured loans in total bank lending rose from 50 percent in 2002 to almost 80 percent in 2006" (World Bank, 2007: 47).

However, despite these disconcerting trends, creditor confidence is at a high. The average spread between interest rates charged on developing country loan commitments and the benchmark LIBOR fell from more than 200 basis points in 2002 to 125 in 2006, as average loan maturities have become longer.

The inevitable conclusion from this evidence that needs explaining is that creditors are not pricing risk adequately and taking it into account when determining exposure. One explanation could be that creditor profiles have changed significantly, with the entry of intermediaries, such as hedge funds and other less risk-averse entities, into the credit market. The other could be the growing role of credit derivatives, which allows for risk pooling and the transfer of risk to entities less capable of assessing them.

According to the Financial Times, "The outstanding notional volume of credit derivatives contracts has doubled every year since the start of this decade to reach $\$ 26,000 \mathrm{bn}$ in the middle of last year. This has led many traditional credit investors to rethink their strategies. But above all, it has triggered a sharp increase in the number and scale of credit-focused hedge funds. In 1990, according to Hedge Fund Research (HFR), hedge funds focused on fixed income strategies accounted for just over 3 per cent of the $\$ 39 \mathrm{bn}$ of assets under management in the industry. By the end of last year, a more varied array of creditrelated strategies accounted for almost 7.5 per cent of a $\$ 1,400 \mathrm{bn}$ industry - and that does not include convertible bond arbitrage. Similarly, the volume of assets under management in fixed-income arbitrage 
strategies alone, which seek to exploit price differences between related bonds and rely heavily on derivatives, has leapt from $\$ 5.8 \mathrm{bn}$ in 2001 to $\$ 41 \mathrm{bn}$ at the end of 2006, according to HFR" (Davies and Beales, 2007). Since these developments are also taking place in the emerging markets, hedge funds are looking for roles there as well.

These two aspects are indeed related. The emergence of credit derivatives has rendered credit assets tradable, attracting those looking for quick or early profits. But even here, financial innovation has played a role. Until recently, other than banks, the major players in the credit business were pension funds and insurers. But with equities proving to be inadequately remunerative investments, banks increasingly geared to creating new instruments based on debt, and credit derivatives offering liquid credit instruments, new players - hedge funds and pension funds - have emerged as investors, and new operators - specialized credit funds and managers of collateralized debt obligations - have emerged as providers of instruments.

In sum, a decade after the 1997-1998 crisis we are witnessing trends which imply an increase in financial fragility that can lead to further financial crises, with adverse implications for growth, stability, employment and social welfare. This is the element of continuity in a world that is seen as having changed substantially. Self-regulation clearly does not help. New measures to govern finance and financial flows are needed.

\section{Macroeconomic fall-out of the capital surge}

Besides increasing fragility and vulnerability, the surge in capital flows to developing countries is making the macroeconomic management of these economies increasingly difficult, with potentially adverse implications for development. The growing presence of foreign capital is disconcerting, not just because such flows are in the nature of "hot money" which renders the financial sector fragile, but because efforts to attract such flows and accommodate surges in such flows have macroeconomic implications.

To start with, inasmuch as financial liberalization leads to financial growth and deepening and increases the presence and role of financial agents in the economy, it forces the state to adopt a deflationary stance to appease financial interests. Deflation follows because financial interests favour tax cuts, but oppose deficit financing for a number of reasons. First, deficit financing is said to increase the liquidity overhang in the system, and therefore as being potentially inflationary. Inflation is anathema to finance since it erodes the real value of financial assets. Second, since government spending is "autonomous" in character, the use of debt to finance such autonomous spending is seen as introducing into financial markets an arbitrary player not driven by the profit motive, whose activities can render interest rate differentials - that determine financial profits - more unpredictable. Third, if deficit spending leads to a substantial build-up of the state's debt and interest burden, it may intervene in financial markets to lower interest rates, with implications for financial returns. Financial interests wanting to guard against that possibility tend to oppose deficit spending. Finally, the use of deficits to finance autonomous expenditures by the state amounts to an implicit legitimization of a proactive and interventionist state and a de-legitimization of the market. Since finance generally seeks to de-legitimize the state and legitimize the market, it strongly opposes deficit-financed, autonomous state spending.

Efforts to curb the deficit under a lenient tax regime obviously result in a contraction of public expenditure, especially state investment, which adversely affects growth and employment; curtails social sector expenditures that sets back the battle against deprivation; impacts adversely on food and other subsidies that benefit the poor; and sets off a scramble to privatize profit-earning public assets, which render the self-imposed fiscal strait-jacket self-perpetuating. All the more so since the finance-induced pressure to limit deficit spending is institutionalized through legislation which constitutionally binds the state to eliminating revenue deficits and limiting fiscal deficits to low, pre-specified levels.

\section{E. Implications of curbing the monetized deficit}

This macroeconomic fall-out and its effects are aggravated by the perception that accompanies the financial reform that macroeconomic regulation should rely on monetary policy pursued by an "independent" central bank rather than on fiscal policy. 
The immediate consequence of this perception is the tendency to follow the principle that even the limited deficits should not be "monetized". Fiscal reform was not only concerned with reducing the size of the deficit, but also with the manner in which any given deficit should be financed. In this regard, fiscal reform involved a sharp reduction of the "monetized deficit" of the government and its subsequent elimination. In many countries, this shift away from low-interest borrowing from the central bank has resulted in a sharp rise in the average interest rate for government borrowing, worsening the fiscal problem. This shift, it is argued, is essential for giving the central bank a degree of autonomy, and monetary policy a greater role in the economy. This understanding, in turn, stems from the premise that monetary policy should have a greater role than fiscal manoeuvrability in macroeconomic management.

The question that remains, therefore, is whether this "abolition" of the monetized deficit in order to appease financial capital actually results in central bank independence. It does not if the country is successful in attracting capital leading to a rapid increase in the level of its foreign exchange reserves. Reserve accumulation is the result of pressure on the central bank to purchase foreign currency to shore up demand for and dampen the effects on the domestic currency of excess supplies of foreign currency.

In India's liberalized foreign exchange markets, for example, excess supply leads to an appreciation of the rupee, which in turn undermines the competitiveness of India's exports. Since improved export competitiveness and increased exports are leading objectives of economic liberalization, the persistence of a tendency towards rupee appreciation implies that the reform process is inherently contradictory. Not surprisingly, the central bank and the government have been keen to dampen, if not stall, appreciation. Thus, the Reserve Bank of India's (RBI's) holding of foreign currency reserves has been rising with the surge in capital inflows.

Unfortunately, the RBI's ability to persist with this policy without eroding its ability to control domestic money supply is increasingly under threat. Increases in the foreign exchange assets of the central bank amount to an increase in reserve money, and therefore in money supply, unless the RBI manages to neutralize increased reserve holding by retrenching other assets. If that does not happen, the overhang of liquidity in the system increases substantially, affect- ing the RBI's ability to pursue its monetary policy objectives. Till recently, the RBI has been avoiding this problem through its sterilization policy, which involves the sale of its holdings of central government securities to match increases in its foreign exchange assets. But even this option has now more or less run out. Net Reserve Bank Credit to the government, reflecting the RBI's holding of government securities, fell from Rs 1,673.08 billion at the end of May 2001 to Rs 46.26 billion by December 10, 2004. With its stock of government securities deteriorating, there was little by way of sterilization instruments available with the RBI. To partly deal with this problem, the government launched a Market Stabilization Scheme in April 2004. Under the scheme, the RBI is permitted to issue government securities for sterilization operations, the timing, volume, tenure and terms of which are at its discretion. The ceiling on the maximum amount of such securities that can be outstanding at any given point in time is decided periodically through consultations between the RBI and the Government.

Since the securities created are treated as government deposits with the central bank, it appears as a liability on the balance sheet of the central bank, and reduces the volume of net RBI credit to the central government, which has, in fact, turned negative. By increasing such liabilities subject to the ceiling, the RBI can balance increases in its foreign exchange assets to differing degrees, controlling the level of its assets and, therefore, its liabilities. The money absorbed through the sale of these securities is not available to the government to finance its expenditures, but is held by the central bank in a separate account that can be used only for the redemption or buy-back of these securities as part of the RBI's operations. As far as the central government is concerned, while these securities are a capital liability, its "deposits" with the central bank are an asset, implying that the issue of these securities does not make any net difference to its capital account, and does not contribute to the fiscal deficit. However, the interest payable on these securities has to be met by the central government and appears in the budget as part of the aggregate interest burden. Thus, the greater is the degree to which the RBI has to resort to sterilization to neutralize the effects of capital inflows, the larger is the cost that the government would have to bear, by diverting a part of its resources for the purpose.

There are three consequences of these developments. First, the monetary policy of the central bank 
that has been de-linked from the fiscal policy initiatives of the state, is no more independent. More or less autonomous capital flows influence the reserves position of the central bank and therefore the level of money supply, unless the central bank chooses to leave the exchange rate unmanaged, which it cannot. This implies that the central bank is not in a position to use the monetary lever to influence domestic economic variables, however effective those levers may be. Secondly, the country is subject to a drain of foreign exchange inasmuch as there is a substantial difference between the repatriable returns earned by foreign investors and the foreign exchange returns earned by the RBI from the investment of its reserves in relatively liquid assets. Finally, in its effort to balance the accumulation of foreign exchange assets by retrenching government securities deposited with it by the central government under the Market Stabilization Scheme, the RBI has taken on deposits of such securities to the tune of more than Rs 1,800 billion. Since the interest due on those securities has to be met from the central budget, the Budget for 2007-2008 had provided for an outgo of Rs 37 billion on this account. But the Mid-Year Review estimates that interest payments on bonds issued for this purpose would amount to Rs 82 billion during financial year 2007-2008, necessitating a supplementary demand of Rs 45 billion. Even more money may have to be allocated for the purpose before the next financial year. This would make fiscal management difficult as well. The outcome may be a further cutback in capital and social expenditures.

While partial solutions to this problem can be sought in mechanisms like the Market Stabilization Scheme, it is now increasingly clear that the real option in the current situation is to either curb inflows of foreign capital or encourage outflows of foreign exchange. As the RBI's survey of monetary management techniques in emerging market economies - reported in its Survey of Currency and Finance 2003-04 - makes clear, countries have chosen to use stringent capital control measures or market-based measures, such as differential reserve requirements and Tobin-type taxes to restrict capital inflows.

Countries unwilling to opt for capital control measures are soon forced to loosen capital outflow norms to expend the foreign exchange "acquired" through large capital inflows, because of pressures to prevent any "unbridled" appreciation of the domestic currency. In countries like India, policies adopted with this objective include: substantial expansion of the permission to use foreign exchange for investment abroad by Indian residents; greater flexibility regarding pre-payment of external commercial borrowings by private sector firms; liberalization of "surrender" requirements for exporters, enabling them to hold up to 100 per cent of their proceeds in foreign currency accounts; extension of foreign currency account facilities to other residents, with permission to transfer large sums annually for any legally permissible expenditure in the host country; and allowing banks to liberally invest abroad in high quality instruments.

Thus, one response to the difficulties countries face in managing the recent surge in capital inflows, is to move towards greater liberalization of the capital account. This only aggravates the problems created by excess global liquidity in the first instance.

\section{Conclusion}

To conclude, the evidence is strong that the surge in capital flows to developing countries in recent years is supply-driven and not warranted by the financing needs in these countries. This supplyside driven surge of capital has three kinds of effects: (i) it results in a situation where financial decisions in these countries are increasingly made by international firms seeking environments and pursuing strategies similar to that in their countries of origin, necessitating fundamental changes in financial policies and regulatory structures; (ii) it increases financial vulnerability in these countries resulting in periodic crisis that can have damaging effects on the real economy; and (iii) it leads to macroeconomic adjustments that reduce the fiscal and monetary autonomy of the governments and the central banks in these countries, with potentially adverse consequences for economic growth. If developing countries want to avoid such outcomes in the current environment, the only option they have is that of adopting domestic policies that restrict the volume and the nature of capital inflows into their economies. 


\section{Annex charts}
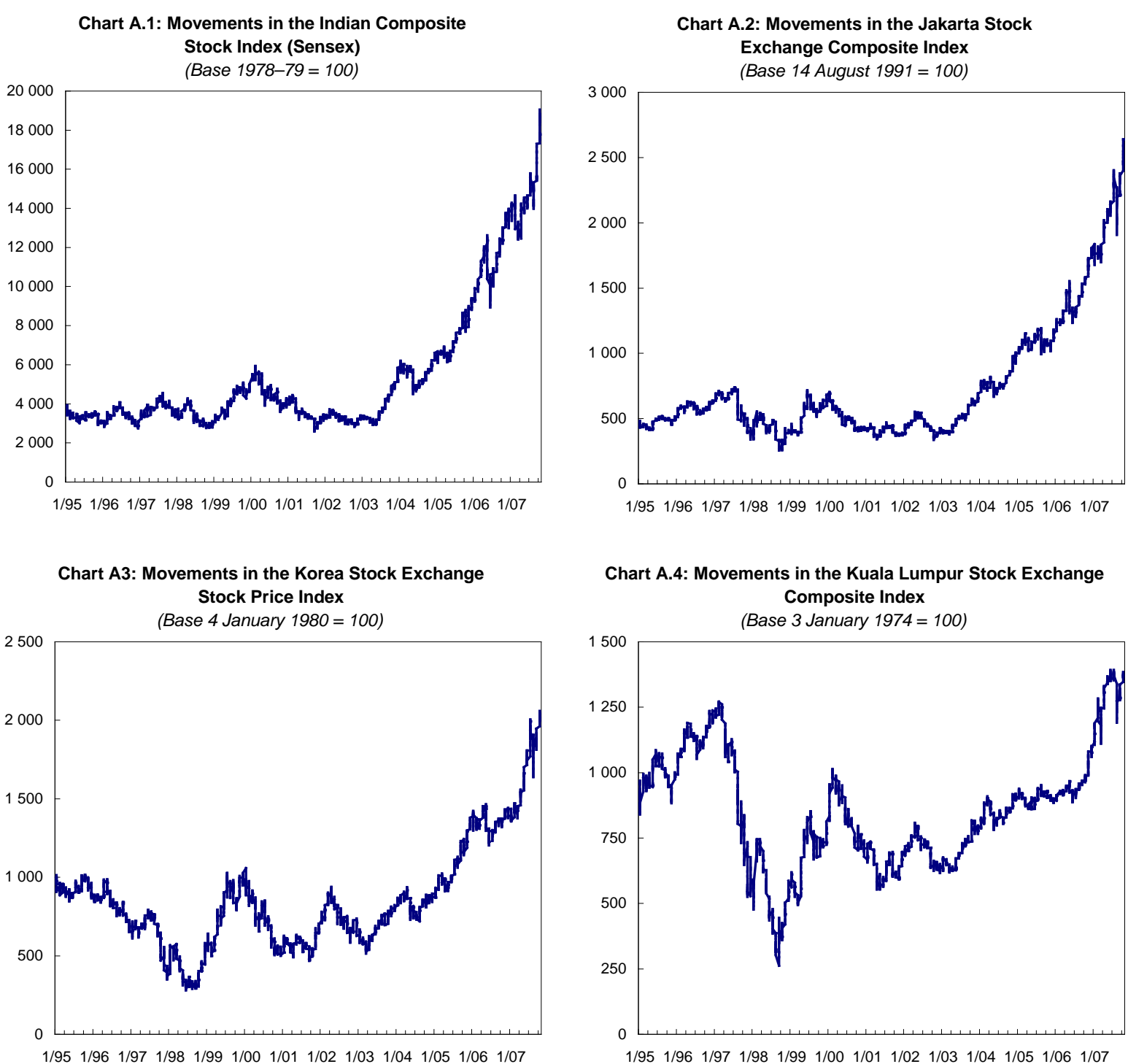

Chart A.4: Movements in the Kuala Lumpur Stock Exchange Composite Index

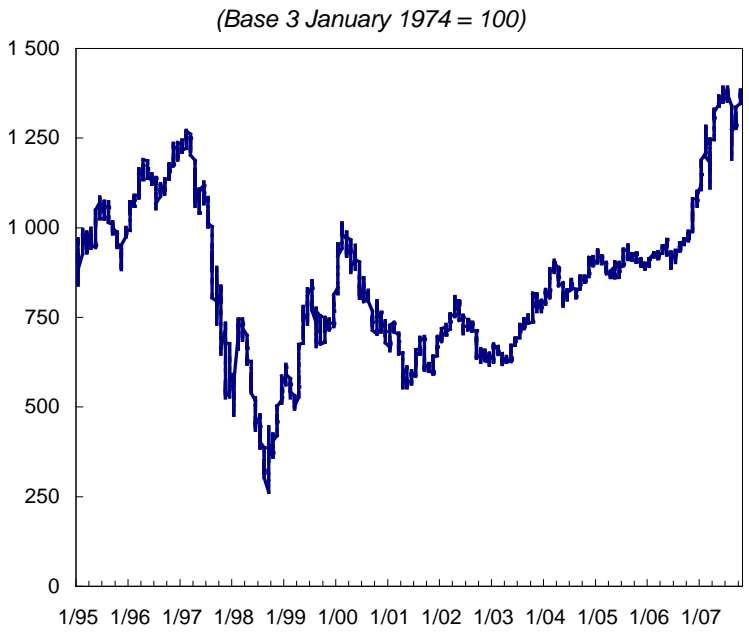

Chart A.5: Movements in the Manila Stock

Exchange Composite Index

SET General Index

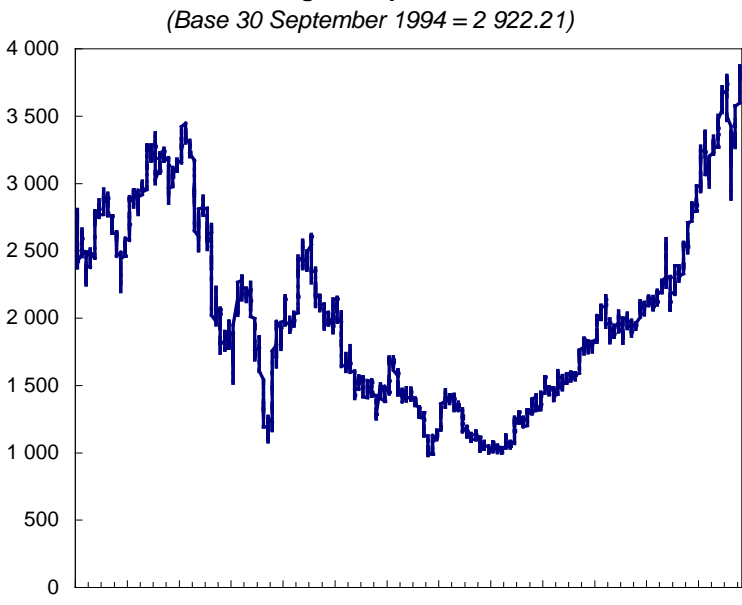

$\begin{array}{lllllllllllll}1 / 95 & 1 / 96 & 1 / 97 & 1 / 98 & 1 / 99 & 1 / 00 & 1 / 01 & 1 / 02 & 1 / 03 & 1 / 04 & 1 / 05 & 1 / 06 & 1 / 07\end{array}$

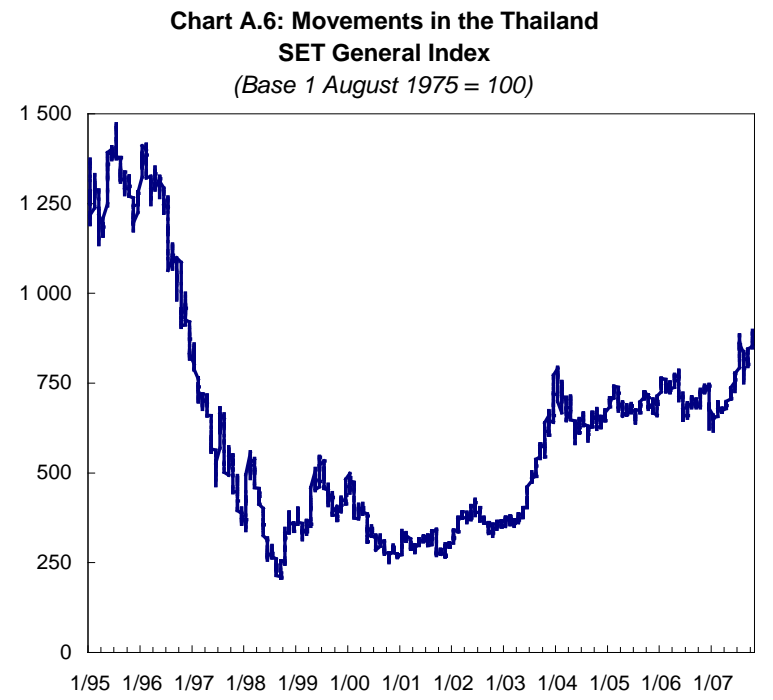

Source: Global Financial Data at www.globalfinancialdata.com. 


\section{Notes}

1 Very often, countries not reporting have been characterised by small or negligible international exposure of banks operating from within their borders. There have been exceptions, such as the Republic of Korea which joined the countries reporting to the BIS in 2005.

2 Figures from Bloomberg and Schumer, 2006.

3 For example, the wealthiest 1 per cent of Americans reportedly earned 21.2 per cent of all income in 2005 , according to data from the Internal Revenue Service. This was an increase in share relative to the 19.0 per cent recorded in 2004, and exceeded the previous high of 20.8 per cent in 2000 , at the peak of the previous bull market in stocks. Compared with this, the bottom 50 per cent earned 12.8 per cent of all income in 2005, which was less than the 13.4 per cent and 13.0 per cent in 2004 and 2000 respectively (Ip, 2007).

\section{References}

BIS (1997). BIS Quarterly Review: International Banking and Financial Market Developments, BIS Reporting Banks: Summary of International Positions: A1-A2. Bank of International Settlements, Monetary and Economic Department, Basel, November.

BIS (2007a). BIS Quarterly Review: International Banking and Financial Market Developments, BIS Reporting Banks: Summary of International Positions: A7-A8. Bank of International Settlements, Monetary and Economic Department, Basel, December.

BIS (2007b). Triennial Central Bank Survey of Foreign Exchange and Derivatives Market Activity in April 2007. Bank of International Settlements, Monetary and Economic Department, Basel.

Bloomberg MR and Schumer CE (2006). Sustaining New York's and the US' Global Financial Services Leadership. Office of the Mayor, City of New York and United States Senate. New York.

Committee on the Global Financial System (2004). Foreign Direct Investment in the Financial Sector of Emerging Market Economies. Bank for International Settlements, Basel.
Committee on the Global Financial System (2007). Institutional Investors, Global Savings and Asset Allocations: Report submitted by Working Group. Bank of International Settlements, Basel.

Creswell J and Bajaj V (2007). A Mortgage Crisis Begins to Spiral, and the Casualties Mount. The New York Times, 5 March.

Davies PJ and Beales R (2007). Introduction: New players join the credit game. The Financial Times, 13 March.

EMPEA (2006). Emerging Markets Private Equity: The current landscape and the road ahead. EMPE Quarterly Review, II (4). Emerging Markets Private Equity Association, Washington, DC, December. Available at: www.empea. net.

Financial Stability Forum (2007). Update of the FSF's 2000 Report on Highly Leveraged Institutions. 18 May. Retrieved 15 June 2007 from Financial Stability Forum: http://www. fsforum.org/publications/HLI_Update-finalwithoutembargo19May07.pdf

Fornari F and Levy A (2000). Global liquidity in the 1990s: geographical allocation and long-run determinants, BIS Conference on International Financial Markets and the Implications for Monetary and Financial Stability, BIS Conference Papers No. 8. Available at: http://www.bis.org/ publ/confer08a.pdf. Accessed 20 December 2007.

Group of 10 (2001). Report on Consolidation in the Financial Sector. 25 January. Retrieved 15 May 2002 from IMF Web site: http://www.imf.org/external/np/g10/2001/01/ Eng/index.htm

Ip G (2007). Income Inequality Widens. The Wall Street Journal, 12 October.

Metrics 2.0 (2006). Asia Pacific Private Equity Deals Tripled in 2006. 16 December. Available at: http://www.metrics2. com/blog/2006/12/13/asia_pacific_private_equity_deals_ tripled_in_2006.html.

OECD (2001). Institutional Investors Statistical Year Book. Organisation for Economic Co-operation and Development, Paris.

OECD (2003). Institutional Investors Statistical Year Book 1992-2001. Organisation for Economic Co-operation and Development, Paris.

World Bank (2007). Global Development Finance 2007: The Globalization of Corporate Finance in Developing Countries. World Bank, Washington, DC. 


\section{G-24 Discussion Paper Series*}

Research papers for the Intergovernmental Group of Twenty-Four on International Monetary Affairs and Development

\begin{tabular}{|c|c|c|c|}
\hline No. 51 & September 2008 & Ugo PANIZZA & $\begin{array}{l}\text { The External Debt Contentious Six Years after the } \\
\text { Monterrey Consensus }\end{array}$ \\
\hline No. 50 & July 2008 & $\begin{array}{l}\text { Stephany GRIFFITH-JONES } \\
\text { with David GRIFFITH-JONES } \\
\text { and Dagmar HERTOVA }\end{array}$ & $\begin{array}{l}\text { Enhancing the Role of Regional Development Banks } \\
\text { S }\end{array}$ \\
\hline
\end{tabular}

$\begin{array}{lll}\text { No. 49 } & \text { December 2007 } & \text { David WOODWARD } \\ \text { No. 48 } & \text { November 2007 } & \text { Sam LAIRD } \\ \text { No. 47 } & \text { October 2007 } & \text { Jan KREGEL }\end{array}$

No. 46 September 2007 José María FANELLI

No. 45

April 2007

Sheila PAGE

No. 44 March 2007

Injoo SOHN

No. 43

February 2007

Devesh KAPUR and

No. 42 November 2006

Richard WEBB

No. 41 October 2006

Mushtaq H. KHAN

No. 40

May 2006

Fernando LORENZO and Nelson NOYA

No. 39 February 2006

Lucio SIMPSON

No. 38

November 2005

Ricardo GOTTSCHALK and Daniela PRATES

IMF Voting Reform: Need, Opportunity and Options

No. 37

April 2005

No. 36

March 2005

Yilmaz AKYÜZ

No. 35 January 2005

Colin I. BRADFORD, Jr.

\section{Aid for Trade: Cool Aid or Kool-Aid}

IMF Contingency Financing for Middle-Income Countries with Access to Private Capital Markets: An Assessment of the Proposal to Create a Reserve Augmentation Line

Regional Arrangements to Support Growth and MacroPolicy Coordination in MERCOSUR

The Potential Impact of the Aid for Trade Initiative

East Asia's Counterweight Strategy: Asian Financial Cooperation and Evolving International Monetary Order Beyond the IMF

Governance and Anti-Corruption Reforms in Developing Countries: Policies, Evidence and Ways Forward

IMF Policies for Financial Crises Prevention in Emerging Markets

The Role of the IMF in Debt Restructurings: Lending Into Arrears, Moral Hazard and Sustainability Concerns

East Asia's Growing Demand for Primary Commodities

- Macroeconomic Challenges for Latin America

Reforming the IMF: Back to the Drawing Board

Prioritizing Economic Growth: Enhancing Macroeconomic Policy Choice

JOMO K.S.

Malaysia's September 1998 Controls: Background, Context, Impacts, Comparisons, Implications, Lessons

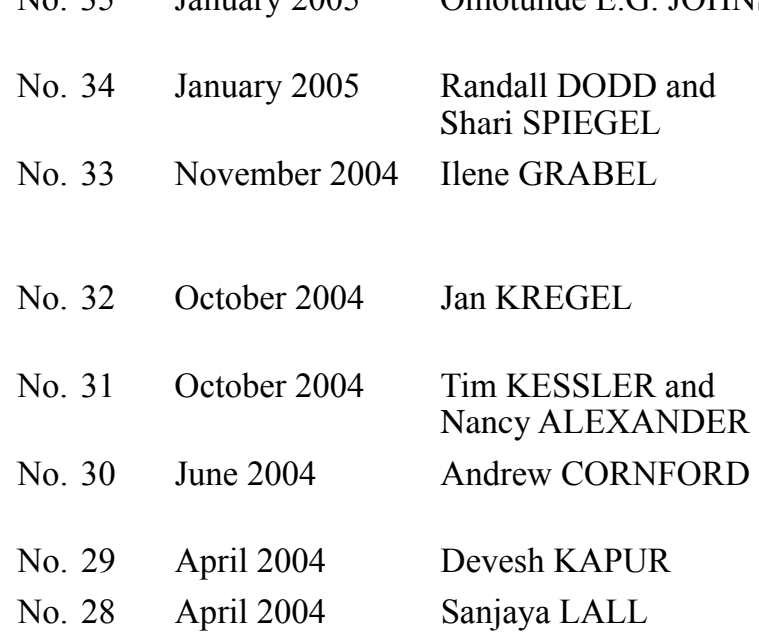

Country Ownership of Reform Programmes and the Implications for Conditionality

Up From Sin: A Portfolio Approach to Financial Salvation

Trip Wires and Speed Bumps: Managing Financial Risks and Reducing the Potential for Financial Crises in Developing Economies

External Financing for Development and International Financial Instability

Assessing the Risks in the Private Provision of Essential Services

Enron and Internationally Agreed Principles for Corporate Governance and the Financial Sector

Remittances: The New Development Mantra?

Reinventing Industrial Strategy: The Role of Government Policy in Building Industrial Competitiveness 


\begin{tabular}{|c|c|c|}
\hline No. 27 & March 2004 & $\begin{array}{l}\text { Gerald EPSTEIN, } \\
\text { Ilene GRABEL } \\
\text { and JOMO, K.S. }\end{array}$ \\
\hline No. 26 & March 2004 & Claudio M. LOSER \\
\hline No. 25 & January 2004 & Irfan ul HAQUE \\
\hline No. 24 & December 2003 & Aziz Ali MOHAMMED \\
\hline No. 23 & November 2003 & Mari PANGESTU \\
\hline No. 22 & August 2003 & Ariel BUIRA \\
\hline No. 21 & April 2003 & Jim LEVINSOHN \\
\hline No. 20 & February 2003 & Devesh KAPUR \\
\hline No. 19 & December 2002 & Ravi KANBUR \\
\hline
\end{tabular}

No. 18 September 2002 Ajit SINGH

\begin{tabular}{|c|c|c|}
\hline No. 17 & April 2002 & F. LÓPEZ-DE-SILANES \\
\hline No. 16 & January 2002 & $\begin{array}{l}\text { Gerardo ESQUIVEL and } \\
\text { Felipe LARRAIIN B. }\end{array}$ \\
\hline No. 15 & December 2001 & $\begin{array}{l}\text { Peter EVANS and } \\
\text { Martha FINNEMORE }\end{array}$ \\
\hline No. 14 & September 2001 & Charles WYPLOSZ \\
\hline No. 13 & July 2001 & José Antonio OCAMPO \\
\hline No. 12 & July 2001 & $\begin{array}{l}\text { Yung Chul PARK and } \\
\text { Yunjong WANG }\end{array}$ \\
\hline No. 11 & April 2001 & Aziz Ali MOHAMMED \\
\hline No. 10 & March 2001 & JOMO K.S. \\
\hline
\end{tabular}
No. 9 February 2001 Gordon H. HANSON
No. 8 January 2001 Ilan GOLDFAJN and Gino OLIVARES

No. 7 December 2000 Andrew CORNFORD

No. 6 August 2000 Devesh KAPUR and

No. 5 June 2000 Andrés VELASCO

No. 4 June $2000 \quad$ Katharina PISTOR

No. 3 May 2000

No. 2 May 2000

No. 1 March 2000
Capital Management Techniques in Developing Countries: An Assessment of Experiences from the 1990s and Lessons for the Future

External Debt Sustainability: Guidelines for Low- and Middle-income Countries

Commodities under Neoliberalism: The Case of Cocoa

Burden Sharing at the IMF

The Indonesian Bank Crisis and Restructuring: Lessons and Implications for other Developing Countries

An Analysis of IMF Conditionality

The World Bank's Poverty Reduction Strategy Paper Approach: Good Marketing or Good Policy?

Do As I Say Not As I Do: A Critique of G-7 Proposals on Reforming the Multilateral Development Banks

International Financial Institutions and International Public Goods: Operational Implications for the World Bank

Competition and Competition Policy in Emerging Markets: International and Developmental Dimensions

The Politics of Legal Reform

The Impact of G-3 Exchange Rate Volatility on Developing Countries

Organizational Reform and the Expansion of the South's Voice at the Fund

How Risky is Financial Liberalization in the Developing Countries?

Recasting the International Financial Agenda

Reform of the International Financial System and Institutions in Light of the Asian Financial Crisis

The Future Role of the International Monetary Fund

Growth After the Asian Crisis: What Remains of the East Asian Model?

Should Countries Promote Foreign Direct Investment?

Can Flexible Exchange Rates Still "Work" in

Financially Open Economies?

Commentary on the Financial Stability Forum's Report of the Working Group on Capital Flows

Governance-related Conditionalities of the International Financial Institutions

Exchange-rate Policies for Developing Countries: What Have We Learned? What Do We Still Not Know?

The Standardization of Law and Its Effect on Developing Economies

The Basle Committee's Proposals for Revised Capital Standards: Rationale, Design and Possible Incidence

Interests and Options of Developing and Least-developed Countries in a New Round of Multilateral Trade Negotiations

The Millennium Round and Developing Countries: Negotiating Strategies and Areas of Benefits

* G-24 Discussion Paper Series are available on the website at: www.unctad.org. Copies of G-24 Discussion Paper Series may be obtained from the Publications Assistant, Macroeconomic and Development Policies Branch, Division on Globalization and Development Strategies, United Nations Conference on Trade and Development (UNCTAD), Palais des Nations, CH-1211 Geneva 10 , Switzerland; Fax (+41-22) 917.0274. 
